DOCTRINA

\title{
The Inter-American Responses during COVID-19: Development of Green Human Rights in Indigenous Cases at the Regional and National Levels
}

\author{
Las respuestas del Sistema Interamericano durante la pandemia por COVID-19: \\ El desarrollo de los derechos humanos verdes en casos de pueblos originarios \\ a nivel nacional y regional
}

\section{Maria Antonia Tigre (iD}

Global Network for the Study of Human Rights, and the Environment

\section{Alexandra Harrington (iD}

Albany Law School, United States

\section{Natalia Urzola (iD}

Global Network for the Study of Human Rights, and the Environment

\section{Hayley Evans}

Global Network for the Study of Human Rights, and the Environment

\section{Alice Kasznar (iD}

Raoul Wallenberg Institute, Denmark

\section{Astrid Bernal (iD)}

Global Network for the Study of Human Rights, and the Environment

\section{Amy van der Kleyn (iD}

Coram Legal Center, United Kingdom

ABSTRACT Latin America is often considered the world's most unequal region. This inequality is not limited to socioeconomic differences; it is also seen through discrepancies in access to nature, land, and natural resources. The Covid-19 pandemic has in- 
tensified existing vulnerabilities felt by communities, especially susceptible to environmental degradation through furthering their socioeconomic disadvantage. Faced with challenges related to the national implementation of certain rule of law concepts and practices, and the lack of access to sufficient domestic remedies, regional plaintiffs have often reached out to the Inter-American system as an arbiter for human rights abuses. Recent jurisprudence of both the Inter-American Court of Human Rights and the InterAmerican Commission on Human Rights has broadened the scope of recognized rights infringed by State Parties to the Inter-American human rights system, particularly in fields relating to environmental issues, natural resource rights and the rights of vulnerable and marginalized communities. Critical to this is the Inter-American Court's development of the inter-dependence of green human rights in Indigenous cases. Set against this backdrop, the Covid-19 pandemic provides an opportunity to analyze existing and evolving legal trends, giving the Inter-American human rights system fertile ground to address emerging legal topics on human rights and the environment. This article addresses this evolving jurisprudence, using recent cases brought to the Commission's attention as case studies on the development of this relationship.

KEYWORDS COVID-19, right to a healthy environment, Inter-American human rights system, indigenous rights, right to water.

RESUMEN Latinoamérica es frecuentemente considerada la región más desigual del mundo. Esta desigualdad no está limitada a una diferencia socioeconómica, sino que también es vista a través de las disputas en el acceso a la naturaleza, tierras y los recursos naturales. La pandemia de Covid-19 ha intensificado vulnerabilidades preexistentes, experimentadas por comunidades especialmente susceptibles a la degradación ambiental, profundizando la desventaja socioeconómica. Enfrentados a retos relacionados con la implementación nacional de ciertos conceptos y prácticas del Estado de derecho, así como la falta de acceso a mecanismos de compensación adecuados a nivel nacional, los demandantes regionales han acudido al Sistema Interamericano como árbitro de abusos a los derechos humanos. La jurisprudencia reciente tanto de la Corte Interamericana de Derechos Humanos como de la Comisión Interamericana de Derechos Humanos ha ampliado el objeto de los derechos reconocidos e infringidos por los Estados parte, particularmente en el ámbito de los asuntos ambientales, derechos de los recursos naturales, y derechos de las comunidades vulnerables y marginadas. De especial importancia es el desarrollo que la Corte Interamericana ha realizado en lo que respecta a la interdependencia de los derechos humanos verdes en los casos de pueblos indígenas. En este contexto, la pandemia de Covid-19 provee una oportunidad para analizar las tendencias legales existentes y en construcción, en un contexto en que el Sistema Interamericano se ha convertido en un escenario conveniente para abordar los asuntos emergentes sobre derechos humanos y medio ambiente. Este artículo aborda esta jurisprudencia revisando casos recientes que han sido llevados a la Comisión.

PALABRAS CLAVE COVID-19, derecho a un medio ambiente sano, Sistema Interamericano de Protección de los Derechos Humanos, derechos indígenas, derecho al agua. 


\section{Introduction}

Since it was first reported to the World Health Organization (WHO) under the requirements set out in the International Health Regulations (IHRs), SARS-CoV-2, better known as Covid-19, has altered lives and laws across the globe. From the first lockdown requirements in Wuhan to the global lockdown, which has persisted for months, all aspects of life and livelihoods have been impacted. These impacts have been felt dramatically throughout Latin America and the Caribbean (LAC), where the combination of large cities, marginalized communities with minimal legal and societal protections, pre-existing gaps in socioeconomic equality and already strained health infrastructure has laid the foundation for significant harms from Covid-19 and the responses to it.

Environmental concerns are deeply interwoven with the pandemic (Etty et al., 2020). Amid the devastation caused by Covid-19, there has been an increasing awareness of the importance of a healthy environment in combating disease and preventing future pandemic outbreaks (Altizer et al., 2013; Farnese, 2014). The timing of this discussion is critical, as it follows a string of cases from the Inter-American human rights system (IAHRS) and some national courts in which the right to a healthy environment and the associated rights of Indigenous communities to preserve their lands and natural resources have come to the forefront.

At the same time, the pandemic provides the opportunity to reflect on the naturesociety relationship and to analyze how the constant pressure on the limited resources of the planet has led to a natural crisis, facilitating the spread of new viruses once controlled by natural barriers which are no longer as strong as before (Medina, Rosales, and Martínez, 2020). For example, at the beginning of the pandemic, environmentalists pointed out a temporary reduction in greenhouse gas (GHG) emissions, shortly followed by a rise in wildlife hunting and problems related to hazardous waste management.

All these environment-related adverse consequences derived from the current crisis shone a light on a long-debated dichotomy: whether to continue with the same practices where nature is seen as a commodity or to transition towards a new reality, where already discussed concepts are further developed and strengthened to expand the protection of natural resources and the embedding of the right to a healthy environment as a matter of law (Martinez and Acosta, 2017; Pecharroman, 2018). The debate surrounding the direction the world should take while building back better is the perfect avenue to advance existing environmental goals, both at an international and national level (Medina, Rosales, and Martínez, 2020). This article contributes to this discussion.

At the core of the debate on integrating environmental and social concerns lies the role of Indigenous populations. With an ancestral relationship with nature and land, Indigenous groups are at the core of our response to the pandemic and its future. 
Yet as discussed in this article, despite an evolving jurisprudence, Indigenous claims are often excluded from mainstream dialogue (Tănăsescu, 2020; Macpherson, Torres Ventura, and Clavijo Ospina, 2020). Their roles in helping prevent future pandemics and the devastating effects this pandemic has had on them, must be included.

This article addresses the confluence of the Covid-19 pandemic, efforts to design a recovery from the pandemic, the evolving nature of the right to a healthy environment, and associated rights (collectively, "green jurisprudence") throughout the IAHRS and at the national level. We critically assess how the green jurisprudence at the IAHRS has been used to respond to the pandemic at the regional level, and how that compares to national level responses, exemplified here through cases in Brazil, Colombia, and Mexico. It then confronts the potential for expanding on the evolution of the Inter-American jurisprudence and practice to cement the concept of the right to a healthy environment as a matter of regional and national case law that can be transformative for marginalized communities, especially Indigenous communities, and the preservation of the environment for current and future generations.

\section{Development of a Green Jurisprudence in the IAHRS}

Covid-19 has posed a significant challenge to almost every aspect of human life. From limiting our mobility and confining us to our homes to underscoring the consequences of pushing the limits of the environment, including some of its features such as water and forests, the pandemic has shed light on how humans' approach to life is in dire need of change. The right to water is among the most affected due to the consequences of Covid-19. It is likely to become a scarce resource due to environmental degradation, which has been heightened by the pandemic ("OHCHR" n.d.). Ironically, this is at the same time that the importance of access to water and proper sanitation facilities is at the heart of national and international efforts to promote hygienic practices that can stop the spread of Covid-19 and other illnesses.

Forests have also proven to protect humans from interactions with animals that could allow for the emergence and transmission of zoonotic diseases, highlighting the continued relevance of deforestation as an issue of concern at all geographic and governmental levels (Afelt, Frutos, and Devaux, 2018). Environmental governance, including forestry, needs to be further developed both at a national and international level, and a key part of that is ensuring inclusive, participative, and just processes where Indigenous and ethnic communities are a crucial part of decision making (Barragán Terán and Muñoz Ávila, 2018). To build back better from Covid-19 and apply the lessons from the pandemic to future planning and practices, it is important to rethink our relationship with nature. This would entail the need to further develop and strengthen green rights, most of which are advancing through regional and domestic systems. 
Decisions from the IAHRS have been known to advance jurisprudence at the international, regional, and national levels. ${ }^{1}$ This is certainly the case in the context of environmental and associated rights. Drawing on the IAHRS's existing green jurisprudence, this section analyzes whether the development of the rights of Indigenous communities, the right to a healthy environment, and the right to water could pave the way towards a post-pandemic future in which our relationship with nature is based on coexistence, not exploitation.

\subsection{Indigenous Rights}

Although generally classified as part of the national sovereignty and rights system of the State in which they are located, Indigenous communities have been recognized as holding specific sui generis rights and being owed specific duties as a matter of international law. The most significant of these systems is the United Nations Declaration on the Rights of Indigenous Peoples (UNDRIP), and the International Labour Organisation Convention No. 169, the Indigenous and Tribal Peoples' Convention. ${ }^{2}$ Combined, these regimes represent non-binding and binding international law, respectively, and are taken as the essential source of many national rights for Indigenous communities. Indeed, the UNDRIP is a critical source of the concept of free, prior, and informed consent (FPIC) discussed below. ${ }^{3}$ Before the advent of these regimes, critical international human rights law regimes such as the International Covenant on Civil and Political Rights (ICCPR), ${ }^{4}$ the International Covenant on Economic, Social, and Political Rights (ICESCR), ${ }^{5}$ and the Convention on the Elimination of All Forms of Discrimination Against Women (CEDAW $)^{6}$ established the rights of people for selfdetermination and control over their natural resources, and the special legal and societal status of rural women. These are rights that can be seen as protecting Indigenous communities and their territories and providing special status for Indigenous women, who are often in rural settings and engaged in agrarian practices. Additionally, the IC-

1. 'Inter-American Court of Human Rights Solidifies the Right to a Healthy Environment', CIEL February 9, 2018, https://bit.ly/2SDn9xG.

2. International Labour Organization, Indigenous and Tribal Peoples Convention, Jun. 27, 1989. https://www.ilo.org/dyn/normlex/en/f?p=NORMLEXPUB:12100:0::NO::P1210o_ILO_CODE:C169.

3. UN General Assembly 61/295, United Nations Declaration on the Rights of Indigenous Peoples: Resolution Adopted by the General Assembly, A/RES/61/295 (Oct. 2, 2007). https://legal.un.org/avl/pdf/ ha/ga_61-295/ga_61-295_ph_e.pdf.

4. International Covenant on Civil and Political Rights (ICCPR), Dec. 16, 1966, 999 U.T. 171 https:// www.ohchr.org/en/professionalinterest/pages/ccpr.aspx.

5. International Covenant on Economic, Social, and Political Rights (ICESCR), Dec. 16, 1966, 993 U.T. 13. https://www.ohchr.org/en/professionalinterest/pages/cescr.aspx.

6. Convention on the Elimination of All Forms of Discrimination Against Women (CEDAW), Dec. 18, 1979, 1249 U.T. 13. https://www.ohchr.org/en/professionalinterest/pages/cedaw.aspx. 
CPR contains special protections for designated national minorities, ${ }^{7}$ the Convention on the Rights of the Child distinguishes between Indigenous peoples and minorities, ${ }^{8}$ and the ICESCR contains rights relating to food, housing, and health that are key to Indigenous communities. ${ }^{9}$ While the UN Convention on the Elimination of All Forms of Racial Discrimination does not explicitly reference Indigenous peoples, the Committee on the Elimination of Racial Discrimination has drawn attention to issues facing Indigenous peoples when reviewing state party reports (Shelton, 2020).

In 1990, the Inter-American Commission on Human Rights (IACHR) created the Rapporteurship on the Rights of Indigenous Peoples to bring attention to Indigenous peoples throughout the region while strengthening, promoting, and systematizing the work of the Commission itself (Neira, 2020). In 1997, the IACHR approved the Draft of the American Declaration on the Rights of Indigenous Peoples, finally adopted in 2016. ${ }^{10}$ This Declaration is considered a milestone in the efforts to promote observance and defense of the human rights of the Indigenous peoples of the Americas. " Since then, the IACHR has received and processed myriad petitions regarding Indigenous communities' issues and potential infringements of their rights. The IACHR has applied the precepts contained in the American Declaration of the Rights and Duties of Man ${ }^{12}$ and the American Convention on Human Rights, ${ }^{13}$ as well as ILO Convention No. 169 to the claims brought before it regarding Indigenous community rights. ${ }^{14}$ As a result, the IACHR has issued several reports, resolutions, and recommendations to States, as well as requests for adopting urgent measures to ensure respect for the rights of Indigenous communities. ${ }^{15}$

7. International Covenant on Civil and Political Rights, Dec. 16, 1966, 999 U.T. 171, at art. 27.

8. Convention on the Rights of the Child, Nov. 20, 1989, 1577 U.T. 3, at art. 30. https://www.ohchr.org/ en/professionalinterest/pages/crc.aspx.

9. International Covenant on Economic, Social, and Political Rights, Dec. 16, 1966, 993 U.T. 13.

10. American Declaration on the Rights of Indigenous Peoples, AG/RES.2888 (XLVI-O/16). https:// www.oas.org/en/sare/documents/DecAmIND.pdf.

11. Organization of American States, The human rights situation of the indigenous people in the Americas OEA/Ser.L/V/II.108 Doc. 62, October 20, 2000. http://www.cidh.org/indigenas/toc.htm.

12. Inter-Am. C.H.R., American Declaration of the Rights and Duties of Man, May 2, 1948. https:// www.cidh.oas.org/basicos/english/basic2.american\%2odeclaration.htm.

13. Organization of American States, American Convention on Human Rights, "Pact of San Jose", Costa Rica, November 22, 1969. https://www.oas.org/dil/access_to_information_American_Convention_on_Human_Rights.pdf.

14. See Inter-Am. Ct. H.R., Advisory Opinions OC 1-83, para. 42, and O.C. 10). The application of the ILO Convention No. 169 is made as a complementary provision for purposes of interpretation (lex specialis) based on the principle of full guarantee established by Articles 29 (b) and 64 of the American Convention. https://www.corteidh.or.cr/docs/opiniones/seriea_o1_ing1.pdf.

15. Comisión Interamericana de Derechos Humanos, Relatoría sobre los Derechos de los Pueblos Indígenas, OEA, http://www.oas.org/es/cidh/indigenas/default.asp. 
The majority of Indigenous community-related claims brought within the IAHRS concern situations where the victims are Indigenous peoples and communities and relate to violations of the rights to life, personal liberty, humane treatment, property, dignity, judicial protection, and a fair trial. In particular, the right to property is highly significant in the discussion of green jurisprudence since it relates to individuals' relationships with the land and each other as members of the Indigenous communities and acts as a guarantee for the enjoyment of other rights. ${ }^{16}$

Originally, the American Convention established a right to property that did not encompass collective land tenure (art. 21). Looking into the evolution of jurisprudence, the IAHRS has accepted the concept of collective rights over land and natural resources in the sense of rights to which groups or organizations of people are entitled and refer to their legal status, the case of Indigenous communities and peoples. ${ }^{17}$ This evolution is an important departure from the traditional conception of property rights as rights of the individual (Shelton, 2020).

The IACHR's most comprehensive defense of collective rights of Indigenous peoples was in the Case of the Miskitos of Nicaragua. ${ }^{18}$ The IACHR then summarized the main claims to (i) a general and wholesome recognition of the Indigenous land as the community held land, as opposed to parcels or sections; (ii) recognition of Indigenous community rights to natural resources within their territories; and (iii) recognition of Indigenous community rights to self-determination and autonomy. ${ }^{19}$

In addition to the individual dimension of the right to property, the Inter-American Court of Human Rights (Court) recognized its collective dimension in $\mathrm{Ma}$ yagna (Sumo) Awas Tingi v. Nicaragua..$^{20}$ The Court specifically applied an evolutive interpretation of art. 21 to conclude that it protects the right to property in a way that comprehends, among others, the rights of members of Indigenous communities in a collective property framework (Pentassuglia, 2011) including cultural and incorpo-

16. Inter-Am. C. H.R., Informe sobre derechos de los pueblos indígenas y tribales sobre sus tierras ancestrales y recursos naturales. Normas y jurisprudencia del Sistema Interamericano de Derechos Humanos, 30 de diciembre de 2009, [3]. https://www.oas.org/es/cidh/indigenas/docs/pdf/tierras-ancestrales. esp.pdf.

17. OAS, The human rights situation.

18. Inter-Am. C.H.R., Resolución sobre el procedimiento de solución amistosa sobre la situación de los derechos humanos de un sector de la población nicaragüense de origen Miskito, OEA/Ser.L/V/II.62, doc. 26 (May 16, 1984), http://www.cidh.org/countryrep/miskitosesp/Resolucion.htm. OAS, The human rights situation.

19. Inter-Am. C.H.R., Report on the situation of human rights of a sector of the Nicaraguan population of Miskito origin, OAS/Ser.L/V/II.62.doc 10 rev.3 and doc. 26, Washington, D.C., 1983, p.24, http:// www.cidh.org/countryrep/Miskitoeng/toc.htm.

2o. Inter-Am. Ct. H.T., Caso de la Comunidad Mayagna (Sumo) Awas Tingni v. Nicaragua, Fondo, Reparaciones y Costas. Sentencia del 31 de agosto de 2001, Serie C, No. 79, [146]. https://www.corteidh. or.cr/docs/casos/articulos/Seriec_79_esp.pdf. 
real elements that derive from traditional lands and native natural resources. ${ }^{21}$ The reasoning points to the holistic ownership tradition within these communities, which is centered on a collective understanding of property, where individuals are not at the core of that relationship but rather the entire community is recognized as the rights holders. Thus, the Court highlighted that the deep connection Indigenous peoples have with the land must be acknowledged as the source for their cultural, spiritual, integrity, and economic survival (Quintana Osuna and Maas, 2017). The Court acknowledged a communitarian tradition related to collective land tenure, which does not necessarily conform to the classic concept of property. Hence, the protection of the Indigenous peoples' right to communal property includes their customary lands and the right to the traditionally used natural resources within their territory (Fuentes, 2016).

This particular aspect is highly relevant to the current Covid-19 crisis, especially given the increased deforestation - such as reported in Brazil (Evans, Ewen, Guillera-Arroita, et al., 2020), Colombia, and Venezuela (Nyekwere, 2020), - forest fires (Guimarães, Azevedo-Ramos, and Moutinho, 2020), and biodiversity loss ${ }^{22}$ that have resulted from measures taken in response to the pandemic. Lockdown has led to reduced enforcement and governmental monitoring, which allowed these activities to thrive amid the pandemic (Evans, Ewen, Guillera-Arroita, et al., 2020). Additionally, these activities, along with a lack of protection from the government, have allowed Covid-19 to spread to Indigenous communities (Cazzolla Gatti et al., 2021; Laudares and Gagliardi, 2020), including those previously secluded. ${ }^{23}$ Adopting a stronger right to Indigenous territory in tandem with a right to a healthy environment could help secure Indigenous rights, as protected in the IAHRS. In the process, this could preserve significant environmental and cultural resources for society as a whole.

Following this case, three other decisions have further recognized the right of Indigenous communities to their ancestral territories, paving the way for stronger green rights in a post-pandemic scenario. These are known as the Paraguayan cases: Caso Comunidad Indígena Yakye Axa v. Paraguay (2005), Caso Comunidad Indígena Sawhoyamaxa v. Paraguay (2006), and Caso Comunidad Indígena Xákmok Kásek v. Paraguay (2010). ${ }^{24}$ In these cases, the Court consolidated rules regarding the collec-

\footnotetext{
21. Ibid [148].
}

22. See also United Nations Office on Drugs and Crime, World Wildlife Crime Report: Trafficking in protected species (New York: UNODC Research, 2020). https://www.unodc.org/unodc/en/data-andanalysis/wildlife.html.

23. See Supremo Tribunal Federal (Br.), Referendo na Medida Cautelar na Arguição de Descumprimento de Preceito Fundamental 709 (Distrito Federal).

24. Inter-Am. Ct.H.R., Case of the Yakye Axa Indigenous Community v Paraguay, Yakye Axa Indigenous Community v Paraguay, Merits, reparations and costs, Series C no 125, IHRL 1509 (IACHR 2005), 
tive ownership and associated rights of Indigenous communities regarding territory identified as Indigenous property. For example, States must delimit and grant collective titles to such lands. Those communities and community members who have lost them have the right to their own interests and control over them restored or to acquire other lands of the same quantity and quality. ${ }^{25}$ Acquiring new land fails to consider the historical and cultural attachment of Indigenous peoples with their land.

In 2013, the IACHR presented the Court with the Pueblos Indigenas Kuna de Madungandí y Emberá de Bayano y sus miembros v. Panamá case. ${ }^{26}$ In this case, there had been a violation of the right to collective property of the communities due to the government's neglect in fulfilling its compensatory obligations resulting from the forced displacement and flooding of ancestral territories following the construction of the Bayano dam, as well as the lack of demarcation and recognition of their lawful land titles. ${ }^{27}$ The case was set to provide a better understanding of the Indigenous right to development and its associated practices. However, the Court failed to fully address the arguments and upheld Panama's preliminary objection to applying the ratione temporis exception ${ }^{28}$, without further analysis of the concept of collective property and what its violation would entail for Indigenous communities. ${ }^{29}$ As per the merits, the Court considered Panama had violated the right to property and judicial protection, as well as to a fair trial due to their failure to delimitate, demarcate and grant deeds over those lands, along with some procedural violations (SarmientoLamus, 2015).

The right to property of Indigenous communities further relies on the obligation of States to guarantee the effective use of lands. ${ }^{30}$ In Comunidad Garifuna de Punta

17th June 2005, https://www.corteidh.or.cr/docs/casos/articulos/seriec_125_ing.pdf; Inter-Am. Ct.H.R., Case of the Sawhoyamaxa Indigenous Community v Paraguay, Sawhoyamaxa Indigenous Community of the Enxet-Lengua people v Paraguay, Merits, reparations and costs, IACHR Series C No 146, IHRL 1530 (IACHR 2006), 29th March 2006, https://www.corteidh.or.cr/docs/casos/articulos/seriec_146_ing. pdf; Inter-Am.Ct.H.R., Case of the Indigenous Community Xákmok Kásek vs. Paraguay, Judgment of August 24, 2010. https://www.corteidh.or.cr/docs/casos/articulos/seriec_214_ing.pdf.

25. OAS, The human rights situation.

26. Inter-Am. Ct.H.R. Caso de los Pueblos Indígenas Kuna de Madungandñi y Emberá de Bayano y sus miembros vs. Panamá, Series C 284, Preliminary objections, merits, reparations and costs, Judgment of 14 October 2014. https://www.corteidh.or.cr/corteidh/docs/casos/articulos/seriec_284_ing.pdf.

27. OAS, The human rights situation.

28. That is, the Court's lack of competence to decide some of the alleged violations since they happened before Panama recognized its contentious competence.

29. Ibid.

3o. Inter-Am. Ct.H.R., Caso comunidad Garífuna de Punta Piedra y sus miembros v. Honduras, excepciones preliminares, fondo, reparaciones y costas. Sentencia del 8 de octubre de 2015. Serie C, No. 304, [181]. https://www.corteidh.or.cr/docs/casos/articulos/seriec_304_esp.pdf\%20. 
Piedra v. Honduras, the Court understood 'effective use' to mean that their lands needed to be protected against the government or third-party actions that undermine their existence, value and impede Indigenous communities to use them according to their customs..$^{31}$ This requires adopting measures to ensure that the land is in proper condition, which means that it should be remediated in case it had been previously interfered with to ensure that Indigenous communities are able to perform their rituals and uphold their traditions, including the use of the land..$^{32}$

Finally, the Court's right to FPIC has also been recognized within the context of the right to property. ${ }^{33}$ FPIC in the LAC context derives from the American Convention, as well as other international instruments such as the ICCPR, the ICESCR, and the UNDRIP (Tigre and Slinger, 2020). It entails a duty of States to guarantee the effective participation of Indigenous communities, under their customs and traditions, in any activity that may take place within their territory. ${ }^{34}$ Other interpretations of this concept evidence an understanding that FPIC requires mere consultation or consent when serious harm is threatened (Shelton, 2020). The right to FPIC has been particularly infringed during the pandemic. For instance, Indigenous representatives have been excluded from emergency plans decision-making processes, and their access to information and on-line platforms has been precarious (COICA et al., 2020). Consultation processes were moved on-line at the beginning of the pandemic under the pretext of protecting Indigenous and Afro-Descendant communities from contracting Covid-19. However, this measure threatened their right to FPIC since it made it harder for them to attend those meetings, and this new forum did not comply with their own decision-making processes..$^{35}$

31. Ibid [172].

32. Ibid [170], [173]-[178].

33. OAS, The human rights situation, citing CIDH, Informe de Fondo No. 40/04, Caso 12.053, Comunidades Indígenas Mayas del Distrito de Toledo vs. Belice, 12 de octubre de 2004, https://www.cidh. oas.org/annualrep/2004sp/Belize.12053.htm; CIDH, Informe de Fondo No. 75/02, Caso 11.140, Mary y Carrie Dann vs. Estados Unidos, 27 de diciembre de 2002, https://www.cidh.oas.org/annualrep/2002sp/ EEUU.1114o.htm. Véase CIDH, Demanda ante la Corte IDH en el Caso de los doce Clanes Saramaka (Caso 13.338) vs. la República de Suriname, 23 de junio de 2006, y la Demanda ante la Corte IDH en el caso del Pueblo Indígena Kichwa de Sarayaku y sus miembros (Caso 12.465) vs. Ecuador, 26 de abril de 2010.

34. OAS, The human rights situation.

35. Open letter to the Colombian Ministry of the Interior and the President of the Republic of Colombia, Mr. Ivan Duque. Copy to: United Nations Special Rapporteur on the rights of indigenous peoples Subject: Colombia's Consultation Fiasco, Underlying Problems and Indigenous Peoples' Solutions Berlin (19 June 2020), https://bit.ly/3gRx6zD. See also Amin Lima da Silva L., Monteiro Joca P., Incumplimiento de los protocolos autónomos de consulta durante el covid-19 en brasil, 1 October 2020, https:// bit.ly/3wNOEU9; A. Mendes, Alcântara: o custo do Centro Espacial para as comunidades quilombolas, 7 December 2017, https://bit.ly/3cZaVX2;R. Oliveira, Ameaça a quilombolas pode travar acordo espacial EUA-Brasil em Alcântara, https://bit.ly/3vSxseB. 
In the 2015 case of Pueblos Kaliña y Lokono v. Suriname, the Court considered whether the State must recognize the juridical personality of Indigenous communities for accountability for human rights violations and other injuries. ${ }^{36}$ The Court recognized that both the Indigenous community members and the community as a whole could be victims of human rights infringement. ${ }^{37}$ The Court specifically considered Indigenous communities to be collective entities of international law and noted that they should be recognized as such. ${ }^{38}$

Based on this analysis, it is possible to observe that the Court's jurisprudence regarding Indigenous rights has tended to revolve around property and resource rights, instead of generating broader discussion on other rights that could help strengthen the protection granted to Indigenous Peoples, such as the right to self-determination and a healthy environment. In this sense, scholars have noticed that the Court prefers to assert art. 21 (right to property) as a general source of Indigenous rights, instead of the more controversial right to self-determination ${ }^{39}$, which, when mentioned in the Court's decisions, is usually dependent and instrumental to ensuring property and resource rights (Garcia and Lixinski, 2020). In regards to the right to a healthy environment, as will be described in the following section, recent measures from the Commission and decisions from the Court are generating important developments regarding the right's scope and justiciability.

In 2019, the IACHR published a report on the "Situation of Human Rights of the Indigenous and Tribal Peoples of the Pan-Amazon Region," providing background to the complex transformations affecting Amazonia, where the human rights of Indigenous communities are being negatively affected by regulations, public policies, expanding natural resource extraction and infrastructure megaprojects (Neira, 2020).

36. Inter-Am. Ct.H.R., Caso Pueblos Kaliña y Lokono vs. Surinam. Fondo, Reparaciones y Costas. Sentencia del 25 de noviembre de 2015. Serie C, No. 309, [305]. https://www.corteidh.or.cr/docs/casos/articulos/seriec_309_esp.pdf.

37. Inter-Am. Ct.H.R., Caso Pueblo Indígena Kichwa de Sarayaku vs. Ecuador. Fondo y Reparaciones. Sentencia del 27 de junio de 2012. Serie C, No. 245, resolutivos 2 y 4 . https://corteidh.or.cr/docs/casos/ articulos/seriec_245_esp.pdf.

38. Inter-Am. Ct.H.R., Titularidad de derechos de las personas jurídicas en el Sistema Interamericano de Derechos Humanos (Interpretación y alcance del artículo 1.2, en relación con los artículos 1.1, 8, 11.2, 13, 16, 21, 24, 25, 29, 30, 44, 46, y 62.3 de la Convención Americana sobre Derechos Humanos, así como del artículo 8.1 A y B del Protocolo de San Salvador). Opinión Consultiva OC22/16 del 26 de febrero de 2016. Serie A, No. 22, 72- 84. https://www.corteidh.or.cr/docs/opiniones/resumen_seriea_22_esp.pdf.

39. Not mentioned in the American Convention or the San Salvador Protocol, the right to self-determination was included after much discussion in the non-binding American Declaration on the Rights of Indigenous Peoples, adopted in 2016, only after member-States were able to ensure that art. 3 establishing self-determination would be followed by an article affirming States' territorial integrity and political unity. 
This report clearly describes the role of oil and gas exploitation, pipeline construction, mining, logging, use of genetic resources, tourism, industrial-scale agriculture, and the establishment of protected areas have played in neglecting the right to FPIC of Indigenous communities. Failure to respect this right has secondary effects, insofar as it jeopardizes the physical and cultural survival of those communities (Neira, 2020).

A total of 16 thematic hearings on Indigenous peoples' rights were held by the IACHR in 2019, where cases regarding the human rights situation of Indigenous peoples in countries including Brazil, Colombia, Nicaragua, Mexico, and Peru were heard. Most of these concern the entry of non-community members onto their territories, the lack of demarcation and titling of their lands, persecution, violence against their leaders and members, and systemic discrimination against Indigenous and Afro-descendant communities (Neira, 2020). This scenario has worsened during the pandemic, as has been demonstrated in Brazil, where the accessing of Indigenous community lands by non-community members, such as construction and mining workers, has been tied to the transition of the virus to members of the Indigenous community.

In light of the critical situation of Indigenous peoples throughout the region during the pandemic, and in line with the IAHRS's jurisprudence, the Commission's Rapporteurship on Economic, Social, Cultural and Environmental Rights (REDESCA) ${ }^{40}$ recommended States to take four sets of measures in regards to Indigenous populations. ${ }^{41}$ First, that States provide information about the pandemic in Indigenous peoples' traditional languages and, where possible, intercultural facilitators to help them understand the effects of the pandemic and the measures carried out by States. Geographical distance, lack of connection to telecommunication networks, social distancing, and government measures restricting movement have been an obstacle for ensuring access adequate information, ${ }^{42}$ which has led many Indigenous and nongovernmental organizations to disseminate information in Indigenous languages. ${ }^{43}$

40. REDESCA replaced the former Unit which focused only on economic, social and cultural rights. Relatoria Especial Sobre Los Derechos Económicos, Sociales, Culturales y Ambientales (2020), https:// www.oas.org/es/cidh/desca/.

41. Inter-Am. Comm. H.R. 2020. Resolution 01/2020 Pandemic and Human Rights in the Americas today. https://www.oas.org/en/iachr/decisions/pdf/Resolution-1-2o-en.pdf.

42. Crisis multidimensional de la pandemia COVID-19 para los Pueblos Indígenas Amazónicos Transfronterizos en Colombia, Ecuador y Perú, Coordinadora de las Organizaciones Indígenas de la Cuenca Amazónica (COICA), https://www.amazonfrontlines.org/chronicles/crisis-multidimensionalde-la-pandemia-covid-19-para-los-pueblos-indigenas-amazonicos-transfronterizos-en-colombiaecuador-y-peru/.

43. Office of High Commissioner for Human Rights, Newsletter: COVID-19 and Indigenous Peoples' Rights (June 29, 2020), https://bit.ly/2SifYuy. 
Second, the IACHR requested States to unconditionally respect non-contact with Indigenous peoples who are in voluntary isolation, a right that many governments in Latin America have continuously failed to protect. Third, in accordance with Indigenous peoples' rights to have their cultures and traditions respected and preserved, and an expression of these peoples' rights to cultural autonomy, the IACHR reminded States that Indigenous peoples are entitled to receive health care that is culturally appropriate, and that considers traditional preventive care, healing practices, and medicines. Fourth, States were advised to refrain from introducing legislation and/or moving forward to carry out production and/or extractive projects in the territories of Indigenous peoples during the pandemic, given the impossibility of conducting FPIC processes due to social distancing measures. Many States, however, have not suspended consultation processes, as described below.

\subsection{Right to a healthy environment}

The right to a healthy environment has been gaining traction in the international forum in the past years (Tigre, 2020a). In 2019, the United Nations General Assembly (UNGA) adopted Resolution 73/333, calling for the adoption of a political declaration to strengthen international environmental law, reinforcing the protection of the environment (Tigre and Lichet, 2020). ${ }^{44}$ Although there is still not one comprehensive international instrument that recognizes the right to a healthy environment, there is a growing push in that direction. ${ }^{45}$ The Covid-19 scenario may be the missing link to ignite this recognition by means of underscoring the gaps in the existing legal frameworks.

The interdependence of the right to a healthy environment and the enjoyment of other human rights have been highlighted during the pandemic, with a special emphasis on the rights of Indigenous communities. The right to health, life, and collective property are among those particularly affected by Covid-19 and its consequences, ranging from increased deforestation and biodiversity loss to land invasions and conflicts that prompt contact with non-Indigenous people. This section analyzes the impact of Covid-19 on the right to a healthy environment by providing an overview of its development within the IAHRS and how it could help in a post-pandemic scenario.

The right to a healthy environment is not enumerated in the American Declaration

44. UN General Assembly, Resolution 73/333, Follow-up to the Report of the Ad Hoc Open-Ended Working Group Established Pursuant to General Assembly Resolution 72/277, A/RES/73/333 (Aug. 30, 2019), https://undocs.org/en/A/RES/73/333.

45. See the work of the Special Rapporteur on Human Rights and the Environment, https://bit. ly/3jakqX8. 
but was expressly guaranteed by its Additional Protocol (San Salvador Protocol). ${ }^{46}$ Nevertheless, its implementation has been challenging due to a lack of comprehensive analysis of the Protocol (Boyd, 2012). This is further complicated by the Protocol's terms, which do not extend rationale materiae jurisdiction over the right to a healthy environment for either the IACHR or the Court. As a result, violations of the right recognized in the Protocol are not subject to individual petitions to the IACHR or the Court. ${ }^{47}$

Before 2017, no IAHRS decision directly included the right to a healthy environment (Bartlett, 2020). Rather, the IACHR and the Court recognized environmental dimensions of the violations of fundamental human rights, such as the right to life and health, in a series of cases..$^{8}$ For example, in Kawas-Fernández v. Honduras, the IACHR concluded that "several fundamental rights require, as a necessary precondition for their enjoyment, a minimum environmental quality, and are profoundly affected by the degradation of natural resources." ${ }^{49}$ It also linked environmental contamination and degradation to a threat to human life and health..$^{50}$

The Court's Advisory Opinion 23/17 significantly advanced environmental rights by relying both on traditional human rights law and on an autonomous right to a healthy environment that is "fundamental to the existence of humanity." ${ }^{11}$ The Court

46. Additional Protocol to the American Convention on Human Rights in the area of Economic, Social and Cultural Rights (Protocol of San Salvador), 28 ILM 156 (1989), 17 November 1988 (entered into force 16 November 1999). Art. 11. https://bit.ly/3x7ygh9.

47. Article 19(6) of the San Salvador Protocol provides for ratione materiae jurisdiction of the Commission and the Court over only two of the rights that it articulates: the right to unionization (Article 8(1)(a)) and the right to education (Article 13). San Salvador Protocol.

48. See e.g., Yanomami v. Brazil, IACtHR, Case 7615, Report No. 12/85, OAS/Ser.L/V/II.66, doc. 10 rev. 1; IACHR, Kawas-Fernández v. Honduras, 3 Apr. 2009, Judgment (Ser. C No. 196), [148]. IACHR, Report on the Situation of Human Rights in Ecuador, OEA/Ser.L/V/II.96 (24 April 1997), ch. 8; Inter-American Commission on Human Rights, Case of Yanomami Indians, Judgment, Case 7615 (Brazil), OEA/ Ser.L/V/II.66 doc.10 rev.1 (1985); IACHR, Access to Justice and Social Inclusion: The Road Towards Strengthening Democracy in Bolivia, OEA/Ser.L/V/II, 28 June 2007, [250-253]; IACHR, Follow-up Report-Access to Justice and Social Inclusion: the Road Towards Strengthening Democracy in Bolivia, OEA/Ser/L/V/II.135, Doc. 40, 7 August 2009, [158].

49. Kawas-Fernández v. Honduras, 3 April 2009 Merits, Reparations, and Costs, Judgment (Ser. C No. 196), [148], https://www.corteidh.or.cr/docs/casos/articulos/seriec_196_ing.pdf. See also IACHR, "Indigenous and tribal people's rights over their ancestral lands and natural resources, norms and jurisprudence of the Inter-American Human Rights System", 30 December 2009. OEA/Ser.I/L/V/II. Doc. 56/09, [190].

50. IACHR, Second Report on the Situation of Human Rights Defenders in The Americas, 31 Dec. 2011, OEA/Ser.L/V/II, Doc. 66, para 309).

51. Inter-American Court of Human Rights, The Environment and Human Rights (State obligations in relation to the environment in the context of the protection and guarantee of the rights to life and 
underscored the unquestionable link between environmental protection and the realization of other human rights affected by environmental degradation, thus reaffirming the interdependence and indivisibility of human rights (Tigre and Urzola, 2021)..$^{52}$ The practical impacts of this interdependence can be seen in the Covid-19 pandemic and responses to it, which have generated significant negative and positive outcomes. On the one hand, a reduction in global GHG emissions and air pollution was experienced worldwide due to the temporary halt in industrial and extractive activities. On the other hand, deforestation rates and biodiversity loss have increased during the pandemic (Fair, 2020). Activities that have amounted to both deforestation and biodiversity loss have directly affected the enjoyment of other human rights, particularly in Indigenous communities who are forced to leave their territories and enter areas where Covid-19 is potentially already spreading (Laudares and Gagliardi, 2020), affecting their right to health, access and use of their ancestral lands. Additionally, forest fires can worsen respiratory diseases, making these communities particularly vulnerable to Covid-19.53

Given the worsening of an already deteriorating environment, the development of environmental and human rights by the Court is essential. Citing precedents from regional and international courts, as well as international instruments and UN resolutions, the Court made clear that a wide range of rights could be adversely affected by the lack of a healthy environment. In the context of Covid-19, the right to health becomes even more relevant given the effects of environmental degradation on people exposed. The Court has interpreted the American Convention as a living instrument, using a transformational and systematic approach..$^{54}$ The majority invoked the reasoning in Lagos del Campo v. Peru, where the Court had previously declared a violation of the right to a healthy environment, considering it directly 'justiciable,' as it falls under the Declaration-based contentious jurisdiction of the San José Tribunal. ${ }^{55}$ This development is particularly important as it brings a particular cause of action for environmental degradation to be questioned within the IAHRS.

In addition to recognizing the right to a healthy environment, the Court expressly acknowledged the right to life as it relates to the environment, noting that an ade-

to personal integrity), interpretation and scope of Articles 4(1) and 5(1) of the American Convention on Human Rights). Advisory Opinion OC-23/17 (15 November 2017). Series A No. 23. Solicitada por la República de Colombia, Medio Ambiente y Derechos Humanos, [59]. https://www.corteidh.or.cr/docs/ opiniones/seriea_23_ing.pdf.

52. Inter-Am. Ct. H.R., OC-23/17, [47, 54, 55, 57, 192].

53. Ibid.

54. Inter-Am. Ct. H.R., OC-23/17, [43-44].

55. Inter-Am. Ct.H.R., Case Lagos del Campo v Peru (August 31, 2017) IACHR Series C No 340. https:// www.corteidh.or.cr/docs/casos/articulos/seriec_340_ing.pdf. 
quate environment, with access to water and food, is essential to human life. The Court further emphasized the mechanisms necessary to ensure that such rights are enforced, in line with those recognized in the Escazú Agreement. It recognized the obligation of States to, for example, abstain from any practice that denies or restricts access to water or food, and that illicitly contaminates the environment, affecting the conditions required for a dignified life (para. 117). This requirement implies a 'positive environmental justice,' which concerns itself not only with human impact on the environment but also with the benefits it provides us, which should be equitably accessed (Cordella and Burdiles, 2019). This is essential during the Covid-19 crisis, which has negatively affected particular groups, including Indigenous groups, in a differentiated manner.

In 2020, the Court reinforced the rationale of a right to a healthy environment in Indigenous Communities Members of the Lhaka Honhat Association vs. Argentina (Tigre, 2020b)..$^{56}$ The case is seen as opening an avenue for the Court to start assessing environmental impacts suffered by Indigenous communities and considering these impacts when determining reparations (Garcia and Lixinski, 2020). The fact that the Court is starting to take positive action towards clarifying the autonomous right to a healthy environment could help secure environmental standards through the progressive development of international environmental law, strengthening the emergent obligation to take measures to prevent environmental harms from a human rights perspective (Boyle, 2012). In REDESCA's Resolution 1/2020, the IACHR also clarified that the human right to health has many social determinants, which are related to the content of other human rights, including environmental rights. ${ }^{57}$

In sum, the Court's recent jurisprudence regarding the living nature of international instruments has advanced the protection and enforcement of human rights, which is essential in the Covid-19 context. One of the main contributions of the 2017 Advisory Opinion is the possibility of holding States responsible for failing to regulate and control environmental damage, opening the door to rights-based litigation on the autonomous right to a healthy environment (Peel and Osofsky, 2018). The adverse effects of the pandemic have directly affected the right to a healthy environment, and its recognition makes such violations directly justiciable under the IAHRS.

56. Inter-Am. Ct. H.R., Caso Comunidades Indígenas Miembros de la Asociación Lhaka Honhat (Nuestra Tierra) vs. Argentina (Feb 6, 2020). https://www.corteidh.or.cr/docs/casos/articulos/seriec_40o_esp. pdf.

57. Inter-Am. Comm. H.R. Resolution 01/2020. 


\subsection{Right to water and sanitation}

Through Resolution 64/292, the UNGA recognized access to drinking water and sanitation as an essential human right and the basis for the enjoyment of other human rights. ${ }^{5}$ Raising the category of access to drinking water to a human right has promoted improvements in its conceptualization and legal development at national levels to progressively advance its realization (Meier et al., 2014). However, the scenario presented by Covid-19 has demonstrated the continuous gaps in the fulfillment and protection of the human rights of ethnic minority communities in certain parts of the world (Laurencin and McClinton 2020). In Latin America, some of the most affected communities have been Indigenous and Afro-descendant peoples (Batista et al., 2020). The conditions of marginalization and systematic violation of their rights, including access to safe drinking water and sanitation, ${ }^{59}$ have made it challenging to face the global health crisis. ${ }^{60}$ This section provides an overview of the development of the right to water at the IAHRS while highlighting how that development plays into the pandemic.

The international recognition of the importance of the human right to water dates to 1977 , when the UN highlighted the importance of water at a global level. ${ }^{61}$ Subsequently, General Observation 15/2002/11 of the Committee on Economic, Social and Cultural Rights, ${ }^{62}$ and Resolutions of the Human Rights Council 7/22 (2008) $)^{63}$ and $12 / 8(2009)^{64}$ reaffirmed the connection between access to safe and clean water and

58. UNGA resolution 64/292, The human right to water and sanitation, A/RES/64/292 (August 3, 2010). https://undocs.org/A/RES/64/292.

59. This right is framed beyond those contemplated by Indigenous peoples, which include access to and control of water resources, as one of the main demands of Indigenous peoples. UNESCO, 2007, Water and Indigenous Peoples. Edited by R. Boelens, M. Chiba, D. Nakashima, and V. Retana. Knowledge of Nature 2, UNESCO: Paris, p. 208.

6o. Economic Commission for Latin America and the Caribbean (ECLAC) and others, "The impact of COVID-19 on the indigenous peoples of Latin America-Abya Yala: between invisibilization and collective resistance", Project Documents (LC / TS.2020 / 171), Santiago, Economic Commission for Latin America and the Caribbean (ECLAC), 2020.

61. UNGA, Follow-up to and implementation of the Mar del Plata Action Plan of the United Nations Water Conference, A/RES/34/191(Dec. 18, 1979), https://bit.ly/3j3H2sG.

62. Office of High Commissioner for Human Rights, UN Committee on Economic, Social and Cultural Rights (CESCR): General Comment No. 15: The Right to Water (Arts. 11 and 12 of the Covenant) (Jan. 20, 2003). https://www.refworld.org/pdfid/4538838d11.pdf.

63. Human Rights Council resolution 7/22, Human rights and access to safe drinking water and sanitation, A/HRC/RES/7/22 (28 March 2008). https://ap.ohchr.org/documents/E/HRC/resolutions/A_HRC_ RES_7_22.pdf.

64. Human Rights Council resolution 12/8, Human rights and access to safe drinking water and sanitation, A/HRC/RES/12/8 (12 October 2009). https://documents-dds-ny.un.org/doc/RESOLUTION/GEN/ Go9/165/71/PDF/Go916571.pdf?OpenElement. 
sanitation. ${ }^{65}$ To emphasize the importance of the enjoyment of a dignified life, international instruments point out the States' duty to give priority to segments of their most vulnerable populations. ${ }^{66}$ Additionally, the American Convention (art. 26) and other international instruments ${ }^{67}$ protect the right of access to water.

In Latin America, five countries ${ }^{68}$ are home to more than 80 percent of the Indigenous population. Of these countries' populations, approximately 8 million $(1.3 \%$ of the regional population), have difficulties accessing drinking water, and more than half of those have limited access to basic sanitation. ${ }^{69}$ Despite being geographically isolated in most cases, the impacts of Covid-19 have exacerbated inequalities in access to water and sanitation in the region, significantly impacting rural Indigenous people under challenging conditions..$^{70}$ For example, for the Wayúu in Guajira, potable water is so limited that a shocking 96 percent lack proper access. ${ }^{71}$ With hand washing and preventative sanitation being two of the main recommendations to stem the spread of Covid-19, and the dispersion of the Wayúu people in isolated ranches making access to basic services challenging, ${ }^{72}$ the Wayúu are especially vulnerable to the virus.

Analyzing the progress in implementing access to water and sanitation as a human right requires studying the joint efforts made by governments, State and non-

65. Human Rights Council resolution 7/22, Human rights and access to safe drinking water and sanitation, $\mathrm{A} / \mathrm{HRC} / \mathrm{RES} / 7 / 22$ (28 March 2008).

66. Office of the High Commissioner for Human Rights, UN Committee on Economic, Social and Cultural Rights (CESCR): General Comment No. 14: The Right to the Highest Attainable Standard of Health (Art. 12) (Aug. 11, 200o), https://www.refworld.org/pdfid/4538838do.pdf.

67. Convention on the Rights of the Child, Article 24, Convention on the Elimination of all Forms of Discrimination against Women, Article 14, Resolutions 2349/o7 and 2760/12 OAS General Assembly, International Covenant on Economic Rights, Social and Cultural, Articles 11 and 12, etc.

68. Five countries are analyzed (Chile, Colombia, Guatemala, Mexico and Peru), selected for being those with the most recent census information, which, in addition, represent $80 \%$ of the Indigenous population of Latin America.

69. Economic Commission for Latin America and the Caribbean (ECLAC) and others, "The impact of COVID-19 on the indigenous peoples of Latin America-Abya Yala: between invisibility and collective resistance", Project Documents (LC / TS.2020 / 171), Santiago, Economic Commission for Latin America and the Caribbean (ECLAC), 2020.

7o. See e.g., Letter from Marcella Ribeiro d’Ávila Lins Torres \& Liliana Andrea Ávila Garcia, Asociación Interamericana para la Defensa del Ambiente, "Situación de pueblos indígenas en Colombia ante la pandemia COVID19," (Apr. 1, 2020), https://bit.ly/2SlFock.

71. Hilary Rosenthal, People of Resilience: Colombia's Wayuu Indigenous Community Confronts a Malnutrition Crisis Amid Covid-19, HRW (Aug. 13, 2020), https://bit.ly/2TVBvtk.

72. Veeduría Ciudadana a La Sentencia T-302 Del 2017, Pervivencia de la Población Wayúu Asentada en el Territorio de la Guajira Durante el Estado de Emergencia por Causa del Nuevo Coronavirus y Que Contemplaría en un Inicio 30 Días a Partir de la Fecha de Publicación-Con Probabilidad de Extensión 12(c) (March 26, 2020), https://bit.ly/3gW5s4l. 
governmental actors to achieve its materialization through public policies and decision-making (Meier et al., 2014). Reviewing national laws and other programs where States are the main actor responsible for realizing rights is crucial (Meier et al., 2014). According to the Court, guaranteeing access to water without discrimination is an immediate obligation that falls on States. ${ }^{73}$

In Resolution No. 1/2020, REDESCA highlighted the precariousness and disparity in access to water and sanitation in the region, making a special call to guide governments to guarantee access to these two rights to reduce the number of infections and ensure the enjoyment of human rights. Subsequently, on July 27, 2020, in Resolution No. 4/2020, the IACHR established a series of guidelines for States to ensure compliance with their obligations to respect and guarantee people's human rights. ${ }^{74}$ To do this, the IACHR emphasized the duty to ensure the highest level of geographic coverage with a particular intercultural approach in terms of Indigenous and Afrodescendant populations and the priority of supplying water to people with Covid-19 to safeguard their rights. ${ }^{75}$

In addition, in March 2020, the UN Group of Experts urged governments to provide free continuous access to water for the duration of the crisis to guarantee hand washing for everyone and thereby avoid increasing the number of infections. ${ }^{76}$ They also pointed out the need to pay special attention to marginalized populations when creating public water and sanitation policies. Countries such as Ecuador, Bolivia, Peru, Colombia, Mexico have taken measures to make charging for services more flexible, cheaper, or are providing water with tanker trucks. ${ }^{77}$

It is not enough to examine the right of access to water and sanitation in an isolated manner in public policies. Rather its materialization requires addressing progress from a perspective based on rights that make it possible to discuss equality and equity in access and governance to ensure compliance with the principle of the universality and interdependence of human rights (London, 2008). These measures are crucial for Indigenous peoples and marginalized populations whose access to water and sanitation infrastructure depends on public budget allocations tied to national political

73. Environment and human rights (state obligations in relation to the environment in the framework of the protection and guarantee of the rights to life and personal integrity - interpretation and scope of articles 4.1 and 5.1, in relation to the Articles 1.1 and 2 of the American Convention on Human Rights). Advisory Opinion OC-23/17, para. 111

74. Inter-Am. Comm. H.R. 2020. Resolution 4/2020 Human Rights of Persons with COVID-19. http://www.oas.org/en/iachr/decisions/pdf/Resolution-4-20-en.pdf.

75. Ibid at para 16,43 .

76. COVID-19 cannot be stopped without providing water to people in vulnerable situations - UN experts. Geneva, 2020. https://bit.ly/3qgoKDo.

77. Agua y COVID-19 en América Latina: la falta de acceso al agua potable aumenta el riesgo de contagio (June 25,2020) https://bit.ly/3wR9SQR. 
and regulatory frameworks. In some cases, even though they are not enough, advances in public policy frameworks are the only means to face inequalities (Cullet, 2013). For example, ensuring the allocation of indigenous water rights could promote innovations in adaptive governance that accommodates water development and restoration of cultural and ecological approaches (Cosens, 2016).

During the Covid-19 pandemic, Indigenous peoples highlighted the lack of access to water and sanitation, evidencing the high risk to which they are exposed given the lack of essential elements to reduce contagion. ${ }^{7}$ In Colombia, the National Indigenous Organization of Colombia (ONIC) noted in April 2020 that the lack of guarantee of essential human rights put about 115,00o Indigenous families in the State at risk (Oquendo 2020). According to Amnesty International, this would be caused by the lack of access to drinking water and other necessary sanitary conditions. ${ }^{79}$ Similarly, only one of four Indigenous communities had access to drinking water in Peru (McCaffrey, 2020).

However, it is not enough to guarantee the installation of western types of infrastructure when it comes to guaranteeing sanitation rights. Under the basis of the principle of universality and in the case of Indigenous peoples, it is necessary to contemplate that interventions address the measures' effectiveness under emergency conditions (Howard et al., 2020) since its effectiveness will depend not only on access to water but also on the possibility of having facilities and means that allow adequate hygiene (Prüss-Ustün et al., 2014). To achieve this, adequate participation processes are crucial. Although guaranteeing sanitation infrastructures does not require the guarantee of access to water as the only measure (Winblad, Kilama, and Others, 1978), its scarcity makes critical hygiene measures and elimination of pathogens through hand washing impossible (Kratzel et al., 2020).

In the case of the Indigenous communities, especially for the Mapuche Indigenous communities in Chile (Sasse, 2020) and the Guarani Kaiowá populations in Brazil, drought and water contamination derived from industrial and agricultural practices and extractivism have left inhabitants exposed without access to means of prevention against Covid-19 (Angelo, 2020). In Mexico, Indigenous communities and Mexican civil society organizations made a joint call to the national government to adopt a preventive and differentiated approach that would involve adequate measures to ensure water and sanitation access during a pandemic. ${ }^{80}$

78. El País (April 2, 2020). Más de 10.000 familias indígenas de Colombia piden protección ante el coronavirus.. Retrieved from: https://bit.ly/35GXabl.

79. Amnesty International. (April 17, 2020) Colombia: Indigenous peoples will be killed by COVID-19 or hunger if the State does not act immediately. Retrieved from: https://bit.ly/3xL9MKu.

8o. Office of the High Commissioner for Human Rights, Los pueblos y comunidades indígenas frente al Covid-19 en México, (May 14, 2020), https://bit.ly/35JqZIp. 
In the regional context, it is essential to highlight the request for precautionary measures made on May 14 before the IACHR by the Center for Justice and International Law (CEJIL) and the Defense Movement for access to water, land, and environmental protection (Modatima) to attend to the emergency of rural communities in the Communes of La Ligua, Petorca and Cabildo, in the Province of Petorca, Valparaíso Region, Chile. ${ }^{81}$ Although the State increased the number of liters delivered to the community utilizing cistern trucks from 50 to 100 liters per day in April 2020, this measure was only temporary. The organizations asserted this access was insufficient, given the risks to the rights to life, health, and integrity, as well as posing additional challenges for rural communities to take preventive measures to avoid contagion of Covid-19. Even though the IACHR recommended strengthening measures to support the right to a healthy environment and water on the basis of equality ${ }^{82}$, the case was dismissed..$^{83}$

The dismissal of the case contradicts the evolving green jurisprudence of the Court, which added access to water to the claims of the Commission in Lhaka Honhat vs Argentina under the application of the iura novit curia principle. ${ }^{84}$ In this case, the court was emphatic in pointing out the duty of States to develop effective measures to guarantee access to water without discrimination, especially for those who have had difficulties accessing this resource, including Indigenous people. The Court also highlighted the 'close interdependence' between the right to a healthy environment, water, food, and cultural identity. Under the stare decisis of the Court, the Argentine State should guarantee, as a measure of reparation, adequate, sufficient, permanent, and accessible ways to the provision of water suitable for human consumption to Indigenous communities following other environmental protection measures for the full enjoyment of rights. ${ }^{85}$

The considerations put forward by the Court reinforce the jurisprudential precedent for action within the member countries of the OAS during the pandemic. The pandemic has highlighted human fragility and the dependence of human health on the planet's environmental health. Covid-19 affected a myriad of human rights ${ }^{86}$

81. CEJIL, Chile: CEJIL and MODATIMA request preventative measures to support rural communities with water scarcity during the COVID-19 Pandemic. (May 14, 2020). https://cejil.org/comunicadode-prensa/chile-cejil-y-modatima-solicitan-medidas-cautelares-a-favor-de-comunidades-rurales-enescasez-hidrica-en-el-marco-del-covidig/.

82. IACHR Issues Preliminary Observations and Recommendations Following On-Site Visit to Chile, (January 31, 2020), https://bit.ly/3vIWEnP.

83. Leoni,M (2020). Aguas Libres. Estándares internacionales sobre el derecho de acceso al agua [Webinar]. Center for Justice and International Law-CEJIL.

84. Inter-Am. Ct. H.R., Lhaka Honhat vs. Argentina (2020).

85. Ibid, at 106.

86. See Zimmermann, Tigre and Saiger (2021). 
and unveiled underlying structural inequalities. Strengthening the recognition of the right of access to water and sanitation for all requires a comprehensive vision of the substantive standards required for its guarantee. Thus, the State's duty to act under the principle of prevention against damages to the environment and the interdependence of rights are crucial to guarantee other human rights depend on it, especially of Indigenous peoples in the region. Advancement in recognizing the right to a healthy environment and its connection with the enjoyment of other rights, including the right to water and sanitation, could promote progress in the development of normative and public policy frameworks where a multisectoral approach is required. A crucial part to implement adequate solutions must be observed from a multicultural recognition of needs, visions and solutions.

Covid-19 is a global threat to human rights. As such, its response should effectively address these threats and provide protection to human rights at both a national and international level. It necessarily includes strengthening the rights of Indigenous groups, and the rights to a healthy environment, health, and water (Tigre, 2021: 2). Doing so will allow better protection of those rights, providing content to what each embodies and encompasses. But it will also provide the procedural mechanisms necessary to ensure their protection, allowing domestic, regional, and international courts to expand their jurisprudence. Furthermore, environmental deterioration has been recognized both as a cause and consequence of the pandemic, so recognizing the right to a healthy environment is crucial (Tigre, 2021: 2). However, unnecessary loss of lives due to Covid-19 can also be traced to a lack of adequate public health policies and responses, failing to fulfill the State's duty to protect (Tigre, 2021: 6). Therefore, a strong recognition of 'green' rights could bolster a better response to the pandemic by both addressing its causes (environmental degradation and human encroachment), and underscoring the need to improve the health system and response measures to health-related emergencies. Higher standards could be secured both in terms of environmental and human health protection. It could also shed a light to the interconnectedness of human rights to better understand how to protect them.

\section{The IAHRS as an avenue for advancing the protection of 'green' rights}

As mentioned in the previous sections, Covid-19 has posed a serious challenge to human rights, especially environment-related rights. The economic crisis following the pandemic is most likely to affect the protection of environmental rights, such as access to clean water, Indigenous community rights, and the right to a healthy environment. Governments have already started to roll back on environmental protection laws and regulations ${ }^{87}$ as a way of coping with this economic crisis and foreseeing a

87. For environmental roll back in the United States see e.g, Harvard Environmental and Energy Law 
false need to rely (more heavily) on extractivism (Cazzolla Gatti et al., 2021). Environmental rights will, without a doubt, face a critical scenario, which makes it even more relevant to find ways to strengthen the protection of green rights. This section analyzes why it is crucial to use the IAHRS as an avenue for advancing the protection of green rights.

Generally speaking, the environment-human rights relationship can be defined through two possible conceptualizations: (i) the environment as a precondition for the enjoyment of human rights; and (ii) the environment as a form of entitlement, that is, an autonomous human right to a healthy environment (Lewis, 2012). The former has been widely recognized and is a well-accepted principle of international human rights law (Shelton 1991). Similarly, human rights fulfillment can also represent a stepping-stone to improve environmental protection (Lewis 2012). Where human rights are satisfied, it is more likely that the government will be better equipped and less distracted with other pressing issues to achieve better environmental protection (Lewis, 2012).

There is an emerging legal trend to recognize the autonomous right to a healthy environment (May and Daly, 2015). Some argue that it should be included in human rights law through a multilateral treaty (Gormley, 1990; Turner, 2004; Lee, 2000) which would bolster the recognition of this right in domestic legal systems and enhance existing environmental protection mechanisms (Lewis, 2012: 41). Although there is currently no broadly applicable multilateral treaty that recognizes the right to a healthy environment, there are some regional treaties and soft-law instruments that do refer to this right, as well as national constitutions that have incorporated it. ${ }^{88}$

Within the region, constitutional evolution has followed two tracks: (i) the duty of the State to protect the environment, and (ii) the right to a healthy environment in and of itself (Aguilar, 2020). However, sometimes the mere inclusion of the right in such instruments may not be sufficient since governments and private individuals may be reluctant to actually implement and enforce this right (Tigre, 2018; Lewis, 2012). This shows that the trend is growing by the day, making it important to study whether the IAHRS could be an appropriate forum to further develop it in a postpandemic scenario.

It is worth mentioning that the trend of recognizing an autonomous right to a

Program (https://bit.ly/zzPMHIL), and the New York University School of Law State Energy and Environmental Impact Center, https://bit.ly/2TSBWF4. For other States: Dom Phillips, 'Brazil Using Coronavirus to Cover up Assaults On Amazon, Warn Act', The Guardian, May 6, 2020, https://bit.ly/3gP 4oAJ. Francisca Albiña, 'SEA Approves Start Of Mining Project in Putaendo Threatening Glacier Area', Fundatión Glaciares Chilenos, April 27, 2020, https://bit.ly/3j4svN1.

88. See Special Rapporteur on the issue of human rights obligations relating to the enjoyment of a safe, clean, healthy and sustainable environment, A/HRC/43/53, (Report, December 2019). 
healthy environment has not been met without controversy. Scholars like Shelton and Alston fear that the proliferation of human rights may devalue existing ones (Shelton, 1991) and it is necessary to assess the delicate balance that ensures the integrity of the tradition of the human rights system and its evolving nature (Lewis, 2012). Other critiques refer to the use of the human rights framework and how it perpetuates an anthropocentric approach to the right to a healthy environment, preventing a more ecocentric one from emerging (Gibson, 1990; MacDonald, 2008). Additionally, scholars have highlighted the tensions and potential opportunities inherent in the creation of environmental jurisprudence and environmentally-focused court systems, including the use of principles of environmental law and principles of sustainable development law (Irarrázabal Sánchez \& Luengo Troncoso, 2018).

In spite of that, it is clear that by using the human rights law framework, environmental protection can be strengthened, and new practical mechanisms can be implemented (Lewis 2012). One avenue to do that is the IAHRS. As discussed in this article, the system has for long used interpretative tools to expand its jurisdiction, which can be seen as acknowledging its role as part of a larger international law system while pushing for its unity (Lixinski, 2010). Both in cases related to environmental rights as well as Indigenous and cultural minorities' rights, the IAHRS has expanded its jurisdiction to include what at first seemed to fall outside its competence. Through cases such as the Community of San Mateo de Huanchor and its Members v. Peru, ${ }^{89}$ Saramaka Community v. Suriname, ${ }^{90}$ Claude Reyes et al. v. Chile, ${ }^{91}$ and Kawas Fernández $v$. Honduras, ${ }^{92}$ the IAHRS has underscored the link between the environment and other human rights such as life, physical integrity, freedom of religion, freedom of information, and the rights of human rights defenders, thus establishing a direct connection that prompts improving environmental protection. Other cases such as the Awas Tingni Case highlight the rights of Indigenous communities in the context of a 'living' American Convention that not only needs to evolve with time but also to make use of other instruments, national and international, to interpret its provisions (Lixinski, 2010). The right to the enjoyment of one's culture has also been construed

89. IACHR, Report n. 69/o4, Petition 504/o3, Admissibility, Community of San Mateo de Huanchor and its Members v. Peru, 15 Oct. 2004, at para. 16.

9o. Inter-Am. Ct. H.R., Case of the Saramaka People v. Suriname, Preliminary Objections, Merits, Reparations, and Costs, Judgment of 28 Nov. 2007, Series C No. 172, at paras 11-17. https://www.corteidh. or.cr/docs/casos/articulos/seriec_172_ing.pdf.

91. Inter-Am. Ct. H.R., Case of Claude-Reyes et al. v. Chile, Merits, Reparations, and Costs, Judgment of 19 Sept. 2006, Series C No. 151, at para. 76. https://www.corteidh.or.cr/docs/casos/articulos/ seriec_151_ing.pdf.

92. Inter-Am. Ct. H.R., Case of Kawas-Fernández v. Honduras, Merits, Reparations, and Costs, Judgment of 3 Apr. 2009, Series C No. 196, at para. 140. https://www.corteidh.or.cr/docs/casos/articulos/ seriec_196_ing.pdf. 
as part of the general provision of the American Convention (art. 1(1)), through cases such as López Alvarez v. Honduras, ${ }^{93}$ where measures preventing individual forms of expression in Indigenous language were considered to amount to a violation of the right to freedom of expression (Lixinski, 2010).

The IAHRS has relied on both international law and national legislation to advance a number of rights, in particular environmental rights. However, some boundaries have been established by the IAHRS as a way of preventing States from exiting, which is why the use of foreign instruments has been sometimes considered to have provided external validation to preexisting rights (Lixinski, 2010). The 'expansionism' of the IAHRS has acted mostly, thus, as a reinforcement of rights already recognized whether in other international instruments or within domestic constitutions, providing an avenue to strengthen environmental protection while remaining cautious of governmental response.

However, compliance with IAHRS' decisions has generally been low. Governments have often refused to abide by or altogether ignored the rulings and orders, which can be seen as undermining their legitimacy and authority (Engstrom, 2017). Sometimes, governments comply with some of the requirements but not all of them, amounting to what has been called a 'compliance crisis' (Engstrom, 2017). However, the number of complaints submitted to the system continues to grow steadily over the last two decades, indicating a sort of validation on the side of those whose rights are being violated (Engstrom, 2017). Despite this apparent paradox, the IAHRS has nonetheless contributed greatly to the development of human rights standards by incorporating a wide range of human rights norms and increasingly expanding the set of human rights issues (Engstrom, 2017). Both the Court, through its progressive jurisprudence, and the IACHR, through its thematic reports and policy guidelines, as well as the IAHRS' accountability functions, have contributed to human rights standards in the region, thus becoming a central reference (Engstrom, 2017). Additionally, the IAHRS' impact can be seen through the increasing insertion of the system into domestic policy, legislative and judicial debates across the region, ${ }^{94}$ which also relates to the fact that it can be used as a means for pressuring states to change domestic political and legal frameworks that conflict with human rights standards (Engstrom 2017)

With that in mind, IAHRS progressive jurisprudence regarding green rights could help advance the protection of these rights in a post-pandemic scenario. To build

93. Inter-Am. Ct. H.R., Case of López-Álvarez v. Honduras, Merits, Reparations, and Costs, Judgment of 1 Feb. 2006. Series C No. 141, at paras 169 and 174.

94. Either through organized civil society action, which has been crucial for advancing this system, or through domestic judicial decisions, who are increasingly invoking IAHRS decisions in domestic matters (Tigre and Urzola, 2020). 
back better, it is necessary to rethink our relationship with nature and the environment, and increased interaction between domestic frameworks and the IAHRS could help to achieve this paradigm shift.

\section{National Case Studies in Green Jurisprudence}

The IAHRS' green jurisprudence has proven to be a key scenario to challenge the environmental issues resulting from the pandemic by means of strengthening the right to a healthy environment, the right to water, and the rights of Indigenous peoples. Likewise, domestic responses can amount to the claim of recognizing a right to a healthy environment as a way of building back better.

Besides the fact that 16 states in the Americas are parties to the Protocol of San Salvador, which recognizes the right to a healthy environment at the regional level, more than 30 States in the Americas have recognized the right to a healthy environment in their constitutions or national legislation (May and Daly, 2015). LAC is considered a 'leading region' in terms of national recognition of this right. ${ }^{95}$ For instance, Ecuador has provided an explicit incorporation of environmental laws and rules, including a particular focus on rights and protections for water and water resources as a critical element of environmental preservation, throughout its system, and, as discussed below, Colombia has enshrined the status of various aspects of environment and natural resources as rights holders (Martínez-Moscoso, 2019).

However, many states have struggled to balance economic growth with the realization of the right to a healthy environment in the region..$^{6}$ For instance, in Brazil, with the expansion of the agricultural sector's economic and political power in the last decades, a series of setbacks in environmental laws and policies that have favored the expansion of large-scale agriculture has occurred (Carvalho, Giessen, and Fernández, 2019). In fact, land-use change in the Amazon has been directly connected to the increase in global demand for agricultural commodities and timber (Nobre et al., 2016) since tropical forests are comparably less profitable than large-scale agriculture (Schmitz et al., 2015).

95. A/HRC/43/54. Human Rights Council, Forty-third session, 24 February-20 March 2020, Agenda item 3, Promotion and protection of all human rights, civil, political, economic, social and cultural rights, including the right to development -Good practices of States at the national and regional levels with regard to human rights obligations relating to the environment. https://undocs.org/en/A/ $\mathrm{HRC} / 43 / 54$.

96. Ibid. 


\subsection{Indigenous rights in Brazil: the rise of legal cases at the national and regional levels}

There are currently an estimated 896,917 Indigenous peoples in Brazil, of which 324,00o live in cities (Instituto Socioambiental, 2019b). In total, they represent 255 ethnic groups that speak 154 languages (Instituto Socioambiental, 2018a). Although representing a small portion of the national population (o.47\% of the State's population), they constitute one of the most diverse ranges of peoples living inside one country in the world (Souza Lima, 2010). Despite the progress in the IAHRS' jurisprudence and in Brazilian legislation, the insufficient protection, realization, and enforcement of Indigenous rights in Brazil are impacting how communities respond to the Covid-19 pandemic.

Rights violations involving Indigenous communities have been recurrent in the Brazilian Amazon, where the pandemic has had a damaging impact. According to Indigenous organizations, ${ }^{97}$ by November 2020 , there were more than 35,000 cases of infected Indigenous persons in the country, and 877 had died from the disease only in Brazil, most of them in the Amazon region (APIB 2020). The region contains the largest area of Indigenous lands (Instituto Socioambiental, 2019a) and almost half of the country's Indigenous population (Instituto Socioambiental, 2018b). At risk is not only the health and lives of Indigenous people but cultural and environmental life and heritage of the region and the country (Bruna Rocha, 2020).

By the time of its enactment, Brazil's 1988 Constitution was considered quite progressive, especially for recognizing a broad spectrum of fundamental rights, including a series of Indigenous collective rights and the right to a healthy environment, and for providing a robust set of norms on environmental protection and sustainable development. The Constitution also recognized Indigenous peoples as the first and natural owners of the land they have occupied and established that all Indigenous lands should have been demarcated (granting land titles to communities) by $1993 .{ }^{98}$ However, out of 724 Indigenous territories, only $487(67 \%)$ have reached the final phase of demarcation (Instituto Socioambiental, 2020). Even when communities have acquired land tenure, lack of enforcement and constant violations of rights, such as the right to a healthy environment or the right to use their natural resources, have hindered the full enjoyment of acquired land rights. For instance, illegal activities in the Amazon are causing environmental degradation in or surrounding Indigenous

97. Brazilian indigenous organizations are compiling their own data on COVID-19 cases arguing that authorities are underreporting the total number of cases since only persons living in indigenous lands are being counted as indigenous. See https://emergenciaindigena.apiboficial.org/dados_covid19/.

98. See arts. 231 and 232 of the Brazilian Constitution, and art. 67 of the Constitution's Transitional Constitutional Provisions Act. 
lands, undermining their livelihoods, and often resulting in violent conflicts (Carneiro Filho and de Souza, 2009). Pollution from illegal mining is further hindering the communities' access to potable water (Bedinelli, 2017).

Several challenges faced by Brazilian Indigenous peoples have been brought to the IACHR. By 2019, at least three hearings focused on the situation of Indigenous Peoples in the country (Neira, 2020). In these hearings, Indigenous organizations brought to the attention of the IACHR the ways in which the then-recently elected Brazilian government was rapidly carrying out legislative and institutional changes that resulted in serious deterioration of Indigenous rights (Neira, 2020). In the "Environmental Protection in the Amazon and the Rights of Indigenous Peoples in Brazil" hearing, Indigenous organizations reported that increased deforestation and fires in the Amazon during 2019 had violated Indigenous Peoples' enjoyment of their human rights and in response, the IACHR underscored "the fundamental role of the Amazon region for the enjoyment of human rights and noted the importance of establishing joint strategies between states that share the Amazon basin in order to combat the threats facing it and to guarantee the right to a healthy environment" (Neira, 2020).

This scenario has worsened during the pandemic. Human rights violations in Brazil are jeopardizing communities' ability to cope with Covid-19. Polluted water hampers sanitation efforts, while forest fires decrease air quality and reduce communities' resilience to respiratory diseases. After a surge in fire hotspots in the Brazilian Amazon in April 2020, Brazil's National Monitoring and Alert Center on Natural Disasters issued an alert due to a possible increase in demand for healthcare (Aragão, Silva Junior, and Anderson, 2020) in a region where hospitals were already saturated by Covid-19 cases (Harari, 2020).

With a growing official disregard of community land rights, the dismantling of environmental protections, and public attention distracted, criminal forest fires and deforestation have risen even more during the pandemic (Guimarães, Azevedo-Ramos, and Moutinho, 2020). Moreover, a recent study showed that there is a significant relationship between deforestation and transmission of Covid-19 to Indigenous communities in Brazil. Until August 31, 2020, deforestation explained at least 22\% of all Covid-19 related cases (Laudares and Gagliardi, 2020). Among the reasons deforestation acts as a facilitator of Covid-19 transmission are: (i) $72 \%$ of deforested lands in 2020 are in conservation areas and Indigenous territories, which entails social interaction either peaceful or violent; (ii) Indigenous communities are already in contact with infected people through activities such as land grabbing, cattle ranching, illegal mining or timber extraction; (iii) deforestation produces forced displacement of Indigenous people, who have to flee to places where the virus may be present; and (iv) fires from the increasing deforestation, combined with other conditions such as droughts and wildfires, worsens respiratory health risks (Laudares and Gagliardi, 2020). 
Invasion of Indigenous lands also became a greater threat during the pandemic. Studies show that frequent entrance of non-Indigenous peoples is one of the main factors leading to contamination by Covid-19 in the Amazon, such as in the case of the Yanomami land (Roman, 2020). Frequently trespassed upon by thousands of illegal miners, the territory, which is home to approximately 27,000 Indigenous persons (Instituto Socioambiental, 2021), among which are some groups living in voluntary isolation, had three deaths from the disease until the first week of June 2020 (Fellet, 2020).

During the IACHR's hearing sessions in 2020, Brazilian Indigenous organizations focused on highlighting the impacts of Covid-19 on this population and in presenting the State's omissions and inefficiencies in protecting Indigenous rights during the pandemic (CIDH, 202ob). The IACHR expressed its concern about the high number of Covid-19 cases among Indigenous peoples in Brazil and emphasized not only the importance of ensuring intercultural health care but also the need to demarcate and protect Indigenous territories in the country (CIDH, 2020a).

This scenario has brought a wide range of legal actions. The Bolsonaro administration was accused of crimes against humanity at the International Criminal Court (ICC), including international environmental crimes. Before the pandemic, in 2019, President Bolsonaro had been denounced at the ICC for the impacts on Indigenous communities of the dismantling environmental and social policies (Grisafi, 2020) and, in 2020, for his mismanagement of the Covid-19 response (Ackerman, 2020) (Uni Global Union, Internacional dos Serviços Públicos, and União Geral dos Trabalhadores, 2020). Even though the ICC has decided not to proceed with investigations (Machado, 2020), they bring international awareness to the ineptness of the Brazilian government to respond to the current crisis. Cases have also been brought at the national and regional levels.

In July 2020, the IACHR published Resolution No. 35/2020 (CIDH, 2020C) highlighting the severe flaws of the Brazilian government in dealing with Covid-19 in the Yanomami land. The Commission requested that Brazil's federal government adopt the necessary actions to protect Indigenous peoples' rights to health, life, and personal integrity. The resolution was a response to a request presented by the $\mathrm{Hu}-$ tukara Associação Yanomami and by Brazil's National Human Rights Council arguing that the specified Indigenous peoples would be at higher risks of contracting Covid-19 due to their particularly vulnerable state, the constant entrance of unauthorized thirdparties in their land and lack of healthcare services and equipment close to their territories (Tigre, 2020c). The IACHR confirmed that the case had all the requisites needed for the Commission to send an urgent request to the Brazilian State, urging the federal government to (i) adopt necessary measures to protect their rights to health, life, and personal integrity, including preventive measures and healthcare services according to applicable international standards; (ii) obtain the communities' agreement on the measures to be adopted; and (iii) report to the IACHR on the measures taken. 
On January 4, 2021, the IACHR issued Resolution 1/2021 (CIDH, 2021) adopting precautionary measures in favor of the Guajajara and Awá Indigenous communities in the context of the pandemic. Petitioners argued that those communities are experiencing a particularly vulnerable situation, given the precarious access to health services and the continuous presence of non-Indigenous people in their territories, which prompts the spread of the disease. Therefore, the Commission concluded that the Brazilian government had to ensure the protection of the rights to health, life, and personal integrity of the members of Indigenous communities against COVID-19, with a culturally appropriate standpoint.

Confirming the federal government's omission in protecting Indigenous rights during the pandemic, in July 2020 the Brazilian Supreme Court, in a preliminary decision, ordered the federal government to take precautionary measures to prevent the spread of Covid-19 in Indigenous territories. The decision was a response to the ADPF ("Ação de Descumprimento de Preceito Fundamental", a specific writ in Brazilian constitutional law against acts or omissions that violate constitutional safeguards) No. 709. ${ }^{99}$ It was the first time this type of writ was filed by an Indigenous organization, confirming its legitimacy to act in the Supreme Court.

In August, the preliminary decision was unanimously confirmed by the plenary. Referencing IACHR's Resolutions 01/2020 and 35/2020, among other legal sources, the judges of the Supreme Court ordered the federal government to take urgent measures such as the creation of sanitary barriers to safeguard communities in isolation and an emergency response room that would include Indigenous representatives. After failing to present an emergency plan on the deadline established by the Supreme Court, the federal government presented an emergency plan on July 29, 2020. The decision also determined that the Indigenous Health Agency should provide healthcare to all non-urban Indigenous persons, not only those living in officially recognized Indigenous territories. The decision did not include an order to immediately remove non-community members from Indigenous lands. As argued by the presiding judge, this should be carefully planned by the federal government.

Even though the measures were requested on the basis of the protection of the right to health and life of Indigenous peoples, in their votes, the judges mentioned the environmental impacts of illegal economic activities developed by invaders in Indigenous territories. They did not, however, seize the opportunity to discuss the interconnections of the government's failure to ensure the constitutional right to a healthy environment and the right to health and life of Indigenous peoples, which would have reinforced the development of the green jurisprudence observed at the regional level.

99. Supremo Tribunal Federal (Br.), ADPF 709. 


\subsection{Ensuring the right to water in Colombia}

Colombia is a country with vast biodiversity and a combination of ethnic communities. It is a multicultural and multilingual country with 87 Indigenous ethnicities, 3 differentiated afro-descendant groups, and a gypsy group (UNDP 2019). A total of 710 Indigenous lands occupy 34 million hectares of territory, which accounts for $29.8 \%$ of the whole country. Most of these territories are found within natural parks (UNDP 2019). There are 132 Black Communities' Collective Territories that occupy over 4 million hectares, that is, $4.13 \%$ of the country's territory (UNDP 2019).

In Colombia, the national government, endorsed by the Constitutional Court, ordered through Decree 441 of March 20, 2020, the aqueduct service's immediate reconnection to people who had it suspended for lack of payment. ${ }^{100}$ In June 2020, the civil society organization Dejusticia requested a constitutional review of Decree 580 of 2020 regarding the provision of the aqueduct, sewerage, and cleaning services during the Covid-19 pandemic, giving priority to vulnerable populations to reduce inequality in access to constitutionally protected rights. ${ }^{101}$ However, although this decree was declared unenforceable, the Colombian Court has already issued different pronouncements concerning the State's duty to guarantee access to water and sanitation as an essential public service for the exercise of the population's rights. ${ }^{102}$

These developments in the context of Colombia must be set against the line of cases beginning with the 2016 decision of the Colombian Supreme Court recognizing the Atrato River as the holder of rights and establishing the appropriate entities to speak and, where necessary, litigate on its behalf. ${ }^{103}$ This was a landmark ruling at the national level - and set a distinctive precedent at the international level - for many reasons, including, notably, the linkage with the right to a healthy environment as well as the right to water, the right to health, the right to life and cultural rights protections (Calzadilla, 2019; Chaves et al., 2020). From this decision, local and intermediary courts have also found entities such as multiple rivers throughout the Colombian State to hold rights connected with the right to a healthy environment and health-related rights (Herrera-Santoyo, 2019). The recognition of the rights of rivers provides an innovative way to ensure the development of green rights, including specifically the human right to safe water, and the preservation of its natural sources as fundamental to guarantee other related rights.

Colombia is increasingly credited as a hotbed for the rights of nature movement, which has its origins in Indigenous philosophies. Yet, the involvement of Indigenous

10o. Dejusticia, Confronting COVID19 in Colombia, http//:www.lse.ac.uk/gender-justice-security. 101. Ibd.

102. Corte Constitucional de Colombia, court decisions: T-570 /1992 ;T-740/2011; C-035/2016, 103. Corte Constitucional de Colombia, T-622/16, 
peoples in these developments is not always obvious (Macpherson, Torres Ventura, and Clavijo Ospina, 2020). In some cases where rivers and related ecosystems are recognized as legal subjects, the courts have ignored or obscured the rights and perspectives of Colombia's Indigenous peoples, even though they and their tenures are directly affected. It is therefore essential to be mindful of the rights and interests of local communities and the social, cultural, and environmental complexities of land tenure so that these innovative legal trends are not lost of purpose (Macpherson, Torres Ventura, and Clavijo Ospina, 2020).

As has been discussed above, the interconnections between the right to a healthy environment and the prevention or facilitation of a pandemic such as the Covid-19 pandemic are fundamental. The IAHRS has recognized the right to a healthy environment through its advisory opinion function, and the fact that this came from a question raised by Colombia should not be overlooked in discussing the place of the right to a healthy environment in the country's context. Taken together, the national court's pronouncements on green rights, including the ability of natural resources to have recognized standing and voices to represent them, and the regional and international legal and treaty systems to which Colombia is a State Party, form a strong potential framework for using human and ecological rights as a means of combating pandemics and public health issues. To do this, however, the State will need to ensure that the entrenchment of these rights is not only a matter for the courts to decide as a matter of first impression, but rather that they become a core and respected element of the statutory and regulatory system.

\subsection{Access rights of Indigenous communities in Mexico}

Mexico is home to 68 Indigenous groups, each speaking a different native language. About 25.7 million persons in the country self-identify as Indigenous, and 7.4 million speak an Indigenous language (Bulkan and Palmer, 2020). Mexico has ratified the ILO Convention 169 and recognized Indigenous peoples' rights in its constitution and laws. In 1992, the Mexican constitution was amended to recognize the country as a pluricultural nation, and in 2001, a series of Indigenous peoples' rights were included in the constitution in a reform that, despite many critiques, explicitly recognized the rights of Indigenous Peoples to autonomy and self-determination (Muciño, 2005).

Despite the progress in recognition of Indigenous peoples' rights in the Mexican legal system, implementation and enforcement of these rights are lagging. As in other Latin American countries, Indigenous communities in Mexico suffer from social, economic, and political marginalization. They are among the most vulnerable social groups in the country, with $69.5 \%$ of the Indigenous population living in poverty and $27.9 \%$ in extreme poverty (Bulkan and Palmer, 2020). Frequently, Indigenous com- 
munities are excluded from decision-making processes despite ratification of international treaties that guarantees the right to consultation and FPIC from Indigenous peoples for the government's legal reforms and administrative acts that may impact them.

The Mayan Train is a governmental railroad projected to go through Mayan lands in southeastern Mexico, including crossing the Selva Maya and the Calakmul Biosphere Reserve (the second largest tropical forest in the Americas) to encourage tourism (Pskowski, 2019). According to Camargo and Vázquez-Maguirre, the planned railroad will go through Mayan archaeological sites, protected natural areas, and Indigenous communities, meaning these will be exposed to mass tourism in addition to the disruption and damage caused by the construction and operation of the railroad itself (Camargo and Vázquez-Maguirre, 2021). This would not only exploit Mayan cultural resources but also the natural resources found in the area for the purposes of tourism. These areas are biologically highly diverse with twenty different ecosystems and endemic species (Camargo and Vázquez-Maguirre, 2021). Train stations along the railroad would mean that the Indigenous communities must grant access to their communal lands.

As the affected Indigenous peoples were not sufficiently consulted in decisionmaking processes regarding the project (López, 2020), the Mayan Train project has generated much controversy. In April 2020, residents of the affected city of Campeche, who faced eviction to make space for the railroad work, sought legal protection from the district courts. Their application at the Court was centered on the lack of information regarding their relocation, fearing homelessness and loss of property. The Court dismissed the application and regarded it as a non-urgent matter. The Mayan Assembly Muuch Ximbal undertook legal action after the government announced the continuous work on the railroad despite Covid-19 restrictions. The Indigenous Assembly urged the suspension of the railroad work due to the risk of spreading and the contamination of Covid-19 to the local Indigenous communities. The Assembly raised concerns that the construction is not essential and that project-related evictions during the pandemic would only serve to put Indigenous peoples further at risk. In a statement, the Mayan Assembly notes that " $[\mathrm{g}]$ iven the fact that the courts of law are not operating normally nationwide, the real possibility that individuals, communities or groups can exercise their access to justice to challenge any act or omission related to this project must be guaranteed.... The agreement that orders the construction of the so-called Tren Maya to be maintained despite the contingency adds to the opacity and lack of information with which the federal government has managed this project" (Staff Writer 2020). ${ }^{104}$

104. 'Is the Mayan Train 'essential' during a pandemic? Yucatán Expat Life Magazine, April 22, 2020, https://bit.ly/2SNMmWo. 
By defining these applications from the affected Indigenous communities as nonurgent, the Mexican federal courts violated the constitutional and procedural rights of these communities to access justice. Additionally, by allowing the increased exposure to Covid-19, these decisions also pose a violation of the right to health (Yucatan Times, 2020). The Covid-19 global health crisis should not facilitate the suspension of constitutional rights in any setting, especially where marginalized and highly atrisk communities are involved. During a state of emergency, it is necessary to ensure the protection of human rights. The Mexican federal courts must take measures to ensure access to justice despite the necessary lockdown restrictions. At the same time, these forms of decisions must also be reviewed against the national obligations incurred as a part of the IAHRS as a State Party to the American Convention on $\mathrm{Hu}-$ man Rights and the Protocol of San Salvador, as well as many other regional human rights instruments. Further, such decisions must be understood within the context of Mexican's core human rights obligations as a State Party, including UNDRIP, ICCPR, and ICESCR.

\section{Conclusion}

As a health crisis that impacts all crevices of society, Covid-19 poses unimaginable human rights challenges the world should have been better prepared to respond to. Yet, as observed from the several claims made to the IAHRS and courts at the national level, States still fail to observe basic human rights obligations such as ensuring proper access to justice or adequate public participation, promoting basic human rights to health, providing fundamental access to water and sanitation, and protecting the environment. These failures have cost the lives of a growing number of people, including those from Indigenous communities, at a disproportionate rate.

The development of a green jurisprudence at the IAHRS throughout the past decades has prepared the regional human rights system to respond to the challenges of the Covid-19 pandemic. Through rapid responses addressing the needs of the communities that have been most impacted by the virus, the IAHRS is attempting to ensure the respect of human rights during the world's most challenging times. However, if enforcement of decisions remains lacking, with no procedural mechanisms to ensure that the measures requested are complied with, human rights will continue to be infringed by States throughout the region. By clearly linking the concepts of green jurisprudence through the IAHRS and national court systems to health and human rights concerns that are associated with the Covid-19 pandemic, there is an opportunity to advance the jurisprudence of the IAHRS system and to prepare it for future issues and global events. 


\section{References}

ACKerman, Tobias (2020). "COVID-19 at the International Criminal Court - Brazil's Health Policy as a Crime against Humanity?” Voelkerrechtsblog, August. https:// bit.ly/3j7UStL.

Afelt, Aneta, Roger Frutos, and Christian Devaux (2018). "Bats, Coronaviruses, and Deforestation: Toward the Emergence of Novel Infectious Diseases?" Frontiers in Microbiology, 9 (April): 702. https://doi.org/10.3389/fmicb.2018.00702.

Aguilar, María Francisca (2020). "Derechos humanos y medio ambiente: La situación de los defensores ambientales en América Latina, y los obstáculos legales e institucionales para su actuar". Anuario de Derechos Humanos, 16 (1): 61-79. https://doi.org/10.5354/0718-2279.2020.53136.

Altizer, Sonia, Richard S. Ostfeld, Pieter T. J. Johnson, Susan Kutz, and C. Drew Harvell (2013). "Climate Change and Infectious Diseases: From Evidence to a Predictive Framework”. Science, 341 (6145): 514-19. https://doi.org/10.1126/science.1239401.

Angelo, Mauricio (2020). "Lack of Clean Water Leaves Brazil Indigenous Reserve Exposed to Coronavirus". Reuters, April 21, 2020. https://reut.rs/3A2boTZ.

APIB (2020). “Dados Covid-19”. Emergência Indígena. 2020. https://emergenciaindigena.apiboficial.org/.

Aragão, Luiz E. O. C., Celso H. L. Silva Junior, and Liana O. Anderson (2020). Brazil's challenge to restrain deforestation and fires in the amazon during covid-19 pandemic in 2020: Environmental, social implications and their governance. sei/ inpe. https://doi.org/10.13140/RG.2.2.11908.76167/1.

Barragán Terán, Daniel, and Lina Muñoz Ávila (2018). “Gobernanza forestal en Colombia y Ecuador: Retos para fortalecer la democracia ambiental en la gestión sostenible de los recursos forestales". Revista de Derecho Ambiental 9: 93-117. doi:10.5354/0719-4633.2018.49747.

Bartlett, Lauren (2020). "Human Rights Guidance for Environmental Justice Attorneys". https://papers.ssrn.com/abstract $=3572357$.

Batista, Amanda, Bianca Antunes, Guilherme Faveret, Igor Peres, Janaina Marchesi, João Pedro Cunha, Leila Dantas, et al. (2020). "Análise socioeconômica sa taxa de letalidade da COVID-19 no Brasil”. Núcleo de Operações E Inteligência Em Saúde (NOIS). May 27, 2020. https://bit.ly/3h3t9YL .

Bedinelli, Talita (2017). "Estamos tomando água poluída, de Mercúrio. O ovo Yanomami Vai Sumir”. El País, April 24, 2017. https://bit.ly/3db6oCC.

Boyd, David R. (2012). “The Constitutional Right to a Healthy Environment." Environment: Science and Policy for Sustainable Development, 54 (4): 3-15. https://doi. org/10.1080/00139157.2012.691392.

Boyle, A. (2012). "Human Rights and the Environment: Where Next?" European Journal of International Law, 23 (3): 613-42. https://doi.org/10.1093/ejil/chs054. 
Bruna Rocha, Rosamaria Loures (2020). "Na Amazônia, as Bibliotecas Estão Sendo Incendiadas". El País, June 3, 2020. https://bit.ly/3vRiQwm.

Bulkan, Janette, and John Palmer (2020). "Mexico." In The Indigenous World 2020, edited by Dwayne Mamo, 438. Copenhagen, Denmark: IWGIA.

Calzadilla, Paola Villiavicenci (2019). "A Paradigm Shift in Courts' View on Nature: The Atrato River and Amazon Basin Cases in Colombia”. Law Env't \& Dev. J. 15: 8. https://bit.ly/2UyxImj.

Camargo, Blanca A., and Mario Vázquez-Maguirre (2021). "Humanism, Dignity and Indigenous Justice: The Mayan Train Megaproject, Mexico". Journal of Sustainable Tourism, 29 (2-3): 372-91. https://doi.org/10.1080/09669582.2020.1758707.

Carneiro Filho, A., and O. B. de Souza (2009). "Atlas de Pressões E Ameaças às Terras Indígenas Na Amazônia Brasileira.” São Paulo: Instituto Socioambiental. https://bit.ly/3vRHY62.

Carvalho, Edson Ferreira, Lukas Giessen, and Encarnación Fernández (2019). “Los principales retrocesos promovidos por la Ley Forestal brasileña de 2012". Revista de Derecho Ambiental, 11: pp. 19-55. doi:10.5354/o719-4633.2019.48434.

Cazzolla Gatti, Roberto, Lumila Paula Menéndez, Alice Laciny, Hernán Bobadilla Rodríguez, Guillermo Bravo Morante, Esther Carmen, Christian Dorninger, et al. (2021). "Diversity Lost: COVID-19 as a Phenomenon of the Total Environment." The Science of the Total Environment 756 (February): 144014. https://doi. org/10.1016/j.scitotenv.2020.144014.

Chaves, Iván Vargas, Gloria Amparo Rodríguez, Alexandra Cumbe Figueroa, and Sandra Estefanía Mora Garzón (2020). "Recognizing the Rights of Nature in Colombia: The Atrato River Case." Jurídicas, 17 (1): 13-41. https://doi.org/10.17151/ jurid.2020.17.1.2.

CIDH (2020a). "Anexo Comunicado de Prensa 253/20 - 177 Periodo de Sesiones." https://bit.ly/3wSHX 36.

-. (2020b). "Períodos de Sesiones Celebrados." Comisión Interamericana de Derechos Humanos. https://bit.ly/3vPCCZ6.

-. (2020c). Resolution 35/2020 - Medida Cautelar No. 563-20. https://bit.ly/3gSgUCI. -. (2021). Resolution 1/2021- Medida Cautelar No. 754-20. https://bit.ly/3qnPxQY.

COICA, CONAIE, CONFENIAE, OZIP, ORPIO, CEDHU, AF, and CEJIL (2020). "Crisis multidimensional de la Pandemia COVID 19 para los pueblos indígenas amazónicos transfronterizos en Colombia, Ecuador y Perú". April 24, 2020. https://bit.ly/3d87AFo.

Cordella, Ezio Costa, and Gabriela Burdiles (2019). "El derecho humano al medio ambiente: Nuevos avances en su comprensión en América Latina y el Caribe". Anuario de Derechos Humanos, 15 (2): 189-212. doi: 10.5354/0718-2279.2019.49296 Cosens, Barbara, and Chaffin, Brian C. (2016). "Adaptive Governance of Water Re- 
sources Shared with Indigenous Peoples: The Role of Law”. Water, 8 (3): 97. https:// doi.org/10.3390/w8030097.

Cullet, Philippe (2013). "Right to Water in India - Plugging Conceptual and Practical Gaps”. The International Journal of Human Rights 17 (1): 56-78. https://doi.org/ 10.1080/13642987.2012.700454.

Engstrom, Par (2017). "Reconceptualising the Impact of the Inter-American Human Rights System / Reconceitualizando O Impacto Do Sistema Interamericano de Direitos Humanos". Direito \& Práxis, 8 (2): 1250-1285. https://doi.org/10.12957/ dep.2017.28027.

Етту, Thijs, Veerle Heyvaert, Cinnamon Carlarne, Bruce Huber, Jacqueline Peel, and Josephine van Zeben (2020). "Indigenous Rights Amidst Global Turmoil”. Transnational Environmental Law, 9 (3): 385-391. https://doi.org/10.1017/ S2047102520000357.

Evans, K. L., J. G. Ewen, G. Guillera-Arroita, J. A. Johnson, V. Penteriani, S. J. Ryan, R. Sollmann, and I. J. Gordon (2020). "Conservation in the Maelstrom of Covid-19 - a Call to Action to Solve the Challenges, Exploit Opportunities and Prepare for the next Pandemic". Animal Conservation 15: 189-196. https://doi.org/10.1111/ acv.12601.

FAIR, James (2020). "COVID-19 Lockdown Precipitates Deforestation across Asia and South America" Mongabay, July 3, 2020. https://bit.ly/2SZjbj2.

FARNeSE, Patricia L. (2014). "The Prevention Imperative: International Health and Environmental Governance Responses to Emerging Zoonotic Diseases." Transnational Environmental Law, 3 (2): 285-309. https://bit.ly/3vW8pr3.

Fellet, João (2020). "Covid-19 Ameaça Aldeias Yanomamis Vizinhas a Garimpo." $B B C$, June 2, 202o. https://bbc.in/3jfaQlQ.

Fuentes, Alejandro (2016). "Judicial Interpretation and Indigenous Peoples' Rights to Lands, Participation and Consultation. The Inter-American Court of Human Rights' Approach." International Journal on Minority and Group Rights 23(1): 3979. https://doi.org/10.1163/15718115-02202006.

GarCIA, Beatriz, and Lucas Lixinski (2020). "Beyond culture: Reimagining the adjudication of indigenous peoples'rights in international law." Intercultural Human Rights Law Review, 15: 127-169. https://bit.ly/3gNRiDJ.

Gibson, Noralee (1990). “The Right to a Clean Environment”. Saskatchewan Law Review, 54: 5. https://bit.ly/2TW9ja2.

Gormley, W. Paul. (1990). "The Legal Obligation of the International Community to Guarantee a Pure and Decent Environment: The Expansion of Human Rights Norms". Georgetown International Environmental Law Review, 3: 85-115. https:// bit.ly/3d $7 \mathrm{keV} 8$. 
GrisAFI, Lily (2020). "Prosecuting international environmental crime committed against indigenous peoples in brazil". Columbia Human Rights Law Review, November. https://bit.ly/3gNRwe3.

Guimarães, André, Claudia Azevedo-Ramos, and Paulo Moutinho (2020). "Covid-19 E O Desmatamento Amazônico”. El País, March 31, 2020. https://bit. ly/3h37xf5.

Harari, Isabel (2020). “Aumento de Desmatamento E Queimadas Deve Piorar Crise de Covid-19 No Xingu." Instituto Socioambiental, June 3, 2020.

Herrera-Santoyo, Héctor (2019). "The Rights of Nature (rivers) and Constitutional Actions in Colombia." The Global Network for Human Rights and the Environment, July 8, 2019. https://bit.ly/2TT9H98.

Howard, Guy, Jamie Bartram, Clarissa Brocklehurst, John M. Colford Jr, Federico Costa, David Cunliffe, Robert Dreibelbis, et al. (2020). "COVID-19: Urgent Actions, Critical Reflections and Future Relevance of 'WaSH': Lessons for the Current and Future Pandemics". Journal of Water and Health, 18 (5): 613-30. https:// doi.org/10.2166/wh.2020.162.

Instituto Socioambiental (2018a). "Direitos Territoriais E Economia Dos Povos Da Floresta No Próximo Mandato Presidencial - Contribuição Do Instituto Socioambiental (ISA) Ao Debate Eleitoral." https://bit.ly/3gWphJ6.

—. (2018b). “Onde Estão?” Povos Indígenas No Brasil. July 13, 2018. https://bit. ly/3wS9Isy.

—. (2019a). "Localização E Extensão Das TIs". Povos Indígenas No Brasil. February 21, 2019. https://bit.ly/zzRRIjM.

—. (2019b). “Quantos São?” Povos Indígenas No Brasil. November 18, 2019. https:// bit.ly/3xHQ5TS.

-. (2020). "Situação Atual Das Terras Indígenas". Terras Indígenas No Brasil. 2020. https://terrasindigenas.org.br/.

—. (2021). “Terra Indígena Yanomami." Terras Indígenas No Brasil. 2021. https://bit. ly/3qjOiCo.

Irarrázabal Sánchez, Ricardo and Luengo Troncoso, Sebastian. (2018). "Aplicación de principios ambientales en el control jurisdiccional del actuar de la Administración". Revista de Derecho Ambiental 9, 1-30. doi:10.5354/0719-4633.2018.49435

Kratzel, Annika, Daniel Todt, Philip V'kovski, Silvio Steiner, Mitra L. Gultom, Tran Thi Nhu Thao, Nadine Ebert, et al. (2020). "Efficient Inactivation of SARS-CoV-2 by WHO-Recommended Hand Rub Formulations and Alcohols." Cold Spring Harbor Laboratory. https://doi.org/10.1101/2020.03.10.986711.

Laudares, Humberto, and Pedro Henrique Gagliardi (2020). "Is Deforestation Spreading COVID-19 to the Indigenous Peoples?". IEPS Working Paper 8. https:// bit.ly/2Uxcwgt. 
Laurencin, Cato T., and Aneesah McClinton (2020). "The COVID-19 Pandemic: A Call to Action to Identify and Address Racial and Ethnic Disparities." Journal of Racial and Ethnic Health Disparities, 7 (3): 398-402. https://doi.org/10.1007/ S40615-020-00756-0.

LEE, John (2000). "The Underlying Legal Theory to Support a Well-Defined Human Right to a Healthy Environment as a Principle of Customary International Law". Columbia Journal of Environmental Law, 25: 283-345. https://bit.ly/3wNO6NU.

Lewis, Bridget (2012). "Environmental Rights or a Right to the Environment?: Exploring the Nexus between Human Rights and Environmental Protection". Macquarie Journal of Comparative and International Environmental Law 8 (1): 36-47. https://papers.ssrn.com/abstract=2673932.

Lixinski, Lucas (2010). "Treaty Interpretation by the Inter-American Court of $\mathrm{Hu}$ man Rights: Expansionism at the Service of the Unity of International Law". European Journal of International Law, 21 (3): 585-604. https://doi.org/10.1093/ejil/ chq047.

London, Leslie (2008). "What Is a Human-Rights Based Approach to Health and Does It Matter?" Health and Human Rights, 10 (1): 65-80. https://doi. org $/ 10.2307 / 20460088$.

López, Eugenia (2020). “Indigenous Communities Win First Battle against AMLO’s Mayan Train.” February 26, 2020. https://bit.ly/3gMQDlY.

MacDonald, Karen E. (2008). "A Right to a Healthful Environment-Humans and Habitats: Re-Thinking Rights in an Age of Climate Change" European Energy and Environmental Law Review, 17(4): 213-226. https://bit.ly/3vTd8d4.

Machado, Renato (2020). "Tribunal Penal Internacional Suspende Denúncias de Crime Contra Humanidade Contra Bolsonaro". Folha de São Paulo, September 17, 2020. https://bit.ly/3vPOTfZ.

Macpherson, Elizabeth, Julia Torres Ventura, and Felipe Clavijo Ospina (2020). "Constitutional Law, Ecosystems and Indigenous Peoples in Colombia: Biocultural Rights and Legal Subjects”. Transnational Environmental Law, 9(3): 521-540. https://papers.ssrn.com/abstract=3697748.

Martinez, Esperanza, and Alberto Acosta (2017). “The Rights of Nature as a Gateway to Another Possible world/Los Derechos de La Naturaleza Como Puerta de Entrada a Otro Mundo Posible". Direito \& Práxis, 8(4): 2927-2961. (December). https://bit.ly/3xHRnhG.

MaY, James R., and Erin Daly (2015). Global Environmental Constitutionalism. Cambridge University Press.

McCaffrey, Carolyn (2020). "In Peru's Amazon, It Will Take More than Soap and Water." Unicef. July 1, 2020. https://uni.cf/3xRvzk3. 
Medina, Valentina Durán, Jorge Ossandón Rosales, and Antonio Pulgar Martínez (2020). "Reflexiones sobre el derecho ambiental en tiempos de pandemia". Revista de Derecho Ambiental, 13: 1-5. doi: 10.5354/0719-4633.2020.57825

Meier, Benjamin Mason, Georgia Lyn Kayser, Jocelyn Getgen Kestenbaum, Urooj Quezon Amjad, Fernanda Dalcanale, and Jamie Bartram (2014). "Translating the Human Right to Water and Sanitation into Public Policy Reform”. Science and Engineering Ethics, 20 (4): 833-48. https://doi.org/10.1007/s11948-013-9504-X.

MuciÑo, Martha Elba Izquierdo (2005). "El reconocimiento de los derechos de los pueblos indígenas en México". Cuadernos Constitucionales de La Cátedra Fadrique Furió Ceriol, 50: 109-24. https://dialnet.unirioja.es/descarga/articulo/2538648.pdf.

NeIRA, Elsy Curihuinca (2020). "Indigenous World 2020: The Inter-American $\mathrm{Hu}$ man Rights System (IAHRC)”. IWGIA. May 11, 2020. https://www.iwgia.org/en/ ip-i-iw/3657-iw-2020-iahrc.html.

Nobre, Carlos A., Gilvan Sampaio, Laura S. Borma, Juan Carlos Castilla-Rubio, José S. Silva, and Manoel Cardoso (2016). "Land-Use and Climate Change Risks in the Amazon and the Need of a Novel Sustainable Development Paradigm". Proceedings of the National Academy of Sciences of the United States of America, 113 (39): 10759-10768. https://doi.org/10.1073/pnas.1605516113.

Nyekwere, Empire Hechime (2020). "The Impacts of the Covid-19 Coronavirus Pandemic on International Environmental Protection". Journal of Law, Policy and Globalization, 101: 96-115. https://bit.ly/3xNgUGt.

Office of the High Commissioner for Human Rights (2000). "UN Committee on Economic, Social and Cultural Rights (CESCR): General Comment No. 14: The Right to the Highest Attainable Standard of Health (Art. 12)". August 11, 2000. https://www.refworld.org/pdfid/4538838do.pdf.

-. (2003). "UN Committee on Economic, Social and Cultural Rights (CESCR): General Comment No. 15: The Right to Water (Arts. 11 and 12 of the Covenant)". January 20, 2003. https://www.refworld.org/docid/4538838d11.html.

-. (2016). "Los pueblos y comunidades indígenas frente al Covid-19 en México." https://bit.ly/35JqZIp.

-. (2020). "Newsletter: COVID-19 and Indigenous Peoples' Rights". June 29, 2020. https://bit.ly/2SifYuy.

OHCHR (n.d.) Accessed January 11, 2021. https://bit.ly/2SlQjB9.

Oquendo, Catalina (2020). "Más de 100.000 familias indígenas de Colombia piden protección ante el coronavirus”. El País, April 2, 2020. https://bit.ly/35GXabl.

Pecharroman, Lidia Cano (2018). "Rights of Nature: Rivers That Can Stand in Court". Resources, 7(1): 13-27. https://doi.org/10.3390/resources7010013.

Peel, Jacqueline, and Hari M. Osofsky (2018). "A Rights Turn in Climate Change Litigation?” Transnational Environmental Law, 7 (1): 37-67. https://doi.org/10.1017/ S2047102517000292. 
Pentassuglia, G. (2011). “Towards a Jurisprudential Articulation of Indigenous Land Rights". European Journal of International Law, 22(1): 165-202. https://doi. org/10.1093/ejil/chroo5.

Prüss-Ustün, Annette, Jamie Bartram, Thomas Clasen, John M. Colford, Oliver Cumming, Valerie Curtis, Sophie Bonjour, et al. (2014). "Burden of Disease from Inadequate Water, Sanitation and Hygiene in Low and Middle-income Settings: A Retrospective Analysis of Data from 145 Countries". Tropical Medicine \& International Health, 19 (8): 894-905. https://doi.org/10.1111/tmi.12329.

Psкowski, Martha (2019). "Mexico's 'Mayan Train' Is Bound for Controversy”. Bloomberg News, February 22, 2019. https://bloom.bg/3wREH87.

Quintana Osuna, Karla I., and Juan Jesús Góngora Maas (2017). Los derechos de los pueblos indígenas y tribales en los sistemas de derechos humanos. Comisión Nacional de los Derechos Humanos, México: Universidad Nacional Autónoma de México.

Roman, Clara (2020). "Covid-19 Pode Contaminar 40\% Dos Yanomami Cercados Pelo Garimpo Ilegal”, June 2, 2020. https://bit.ly/3xH5YKm.

Sarmiento-Lamus, Andrés (2015). "Case of indigenous communities kuna of madungandí and emberá of bayano and its members v. Panama". International Lawyer, 13 (27). https://doi.org/10.11144/javeriana.il15-27.cick.

SASSE, Emilia (2020). "Chile: COVID-19 golpea la esencia del alma mapuche". Deutsche Welle. June 2, 2020. https://bit.ly/3wOobCK.

Schmitz, Christoph, Ulrich Kreidenweis, Hermann Lotze-Campen, Alexander Popp, Michael Krause, Jan P. Dietrich, and Christoph Müller (2015). "Agricultural Trade and Tropical Deforestation: Interactions and Related Policy Options". Regional Environmental Change, 15 (8): 1757-72. https://doi.org/10.1007/s10113-014-0700-2.

Shelton, Dinah (1991). "Human Rights, Environmental Rights, and the Right to Environment”. Stan. J. Int'l L., 28: 103. https://bit.ly/2T3FLqF.

-. (2020). "The Rights of Indigenous Peoples". In Andreas von Arnauld, Kerstin von der Decken, Mart Susi (eds.), The Cambridge Handbook of New Human Rights (pp. 217-232). Cambridge: Cambridge University Press. https://doi. org/10.1017/9781108676106.017.

Souza Lima (2010). "Povos Indígenas No Brasil Contemporâneo: De Tutelados a Organizados?" In Povos Indígenas: Projetos E Desenvolvimento, edited by C. N. I. Sousa, A. C. S. Lima, F. V. R. Almeida, and M. H. O. Matos, II: 6o-8o. Paralelo 15/GTZ/Laced-MNUFRJ.

Staff Writer (2020). “Is the Mayan Train 'essential' during a Pandemic?” Yucatan Expat Life. April 22, 2020. https://bit.ly/3gSN91r.

TĂNĂSESCU, Mihnea. (2020). "Rights of Nature, Legal Personality, and Indigenous Philosophies”. Cambridge, 9 (3): 429-53. https://doi.org/10.1017/S2047102520000217. 
Tigre, Maria Antonia (2018). "Implementing Constitutional Environmental Rights in the Amazon Rainforest". In Implementing Environmental Constitutionalism: Current Global Challenges, edited by Erin Daly \& James, 59-83. Cambridge: Cambridge University Press.

-. (2020a). "Gaps in International Environmental Law: Toward a Global Pact for the Environment”. Environmental Law Institute: Washington, DC, USA. https://bit. ly/3j96k8s.

-. (2020b). "Lhaka Honhat Association vs. Argentina: The Human Right to Environment in the Inter-American Court". GNHRE. April 13, 2020. https://bit. ly/3WRHQEN.

-. (2020c). "How is COVID-19 affecting Amazonia? Violations to Human Rights and the Environment." Vöelkerrechtsblog, August 10, 2020. https://bit.ly/35Pf2kp.

-. (2021). "COVID-19 and Amazonia: Rights-Based Approaches for the Pandemic Response". Review of European, Comparative \& International Environmental Law, https://bit.ly/3j8dF8r.

Tigre, Maria Antonia, and Victoria Lichet (2020). "Update on Negotiation of a New International Environmental Agreement". Environmental Law Reporter, 50 (10): 10818. https://bit.ly/3daHS2P.

Tigre, Maria Antonia, and Sarah C. Slinger (2020). "A Voice in the Development of Amazonia: The Constitutional Rights to Participation of Indigenous Peoples". In Indigenous Amazonia, Regional Development and Territorial Dynamics: Contentious Issues, edited by Walter Leal Filho, Victor T. King, and Ismar Borges de Lima, 7-37. Cham: Springer International Publishing. https://doi. org/10.1007/978-3-030-29153-2_2.

Tigre, Maria Antonia, and Natalia Urzola (2020). "Developing Brazilian Jurisprudence on the Right to a Healthy Environment". Global Network for the Study of Human Rights and the Environment. December 17, 2020. https://bit.ly/3jdZYVH.

-. (2021). "The 2017 Inter-American Court's Advisory Opinion: Changing the Paradigm for International Environmental Law in the Anthropocene". Journal of Human Rights and the Environment, 12 (1): 24-50. https://doi.org/10.4337/ jhre.2021.01.02.

Turner, Steve (2004). "The Human Right to a Good Environment. The Sword in the Stone." Non-State Actors and International Law, 4 (3): 277-301. https://doi. org/10.1163/1571807042794663.

UN, United Nations (1983). "International Covenant on Civil and Political Rights." Opened for signature December 19, 1966. United Nations Treaty Series Online 999, no. 14668 (1983): 171-391. https://bit.ly/3qnKQ9F.

-. (1983). "International Covenant on Economic, Social, and Cultural Rights." Opened for signature December 19, 1966. United Nations Treaty Series Online 993, no. 1453 (1983): 3-106. https://bit.ly/2Snwt8N. 
-. (1989). International Labour Organization. "Indigenous and Tribal Peoples Convention.” June 27, 1989. https://bit.ly/2SS9fYN.

-. (1990). "Convention on the Elimination of all Forms of Discrimination Against Women." Opened for signature March 1, 1980. United Nations Treaty Series Online 1249, no. 20378 (1990): 13-142. https://bit.ly/3xPxVzY.

UndP (2019). “Colombia”. United Nations Development Program. 2019. HTTPS://BIT.LY/3WRI5ZR.

Uni Global Union, Internacional dos Serviços Públicos, and União Geral dos Trabalhadores (2020). "Complaint to the International Criminal Court against Jair Messias Bolsonaro”. https://bit.ly/3gZIhWX.

United Nations General Assembly (2019). "Follow-up to the Report of the Ad Hoc Open-Ended Working Group Established Pursuant to General Assembly Resolution 72/277." A/RES/73/333. August, 30, 2019. https://undocs.org/en/A/ $\mathrm{RES} / 73 / 333$.

United Nations General Assembly (2007). "United Nations Declaration on the Rights of Indigenous Peoples: Resolution Adopted by the General Assembly." A/ RES/61/295. October 2, 2007. https://bit.ly/3wRJGWd.

Winblad, Uno, Wen Kilama, and Others (1978). Sanitation without Water. https:// bit.ly/35MuZb5.

Yucatan Times (2020). "AMLO's Administration Leaves Rural Communities That Oppose the Maya Train Totally Defenseless". April 29, 2020. https://bit.ly/3qkrzWF. Zimmermann, Nesa, Maria Antonia Tigre, and Anna-Julia Saiger (2021). "COVID-19 and "New" Human Rights Symposium." Völkerrechtsblog, March. DOI: 10.17176/20210322-151140-0

\section{About the authors}

Maria Antonia Tigre, Director for Latin America, Global Network for the Study of Human Rights, and the Environment (GNHRE); Coordinator of the Ecological Rights Subgroup of the Global Pandemic Network (GPN), S.JD. Candidate at Elisabeth Haub School of Law, Pace University, New York, USA; Master of Laws (LL.M.) at Elisabeth Haub School of Law, Pace University, New York, USA (2014). Email: tonia. tigre@gmail.com. (D) http://orcid.org/o0oo-0003-4308-1958.

Alexandra Harrington, Doctor of Civil Law, McGill University, Canada (2015), Visiting Assistant Professor of Law at Albany Law School, Albany, NY, USA. Email: arharrington@gmail.com. (D) https://orcid.org/0000-0003-1355-7281.

Natalia Urzola, Master of Laws (LL.M.) at University of California, Berkeley, School of Law, Berkeley, California, USA (2020), Member of the Global Network for the Study of Human Rights and the Environment (GNHRE) and the Ecological 
Rights Subgroup of the Global Pandemic Network (GPN). Email: natalia.urzola.g@ gmail.com. (D) https://orcid.org/oooo-0002-3443-2915.

Hayley Evans, Juris Doctor at Harvard Law School, Cambridge, MA, USA (2020); New York State Bar, Third Judicial Department, 2020; Member of the American Society of International Law. Email: hevans@jd19.law.harvard.edu. (D) https:// orcid.org/0000-0001-7692-024X.

Alice Kasznar, Master in Sustainability Science, 2019, Lund University, Sweden; Jr Programme Associate, Raoul Wallenberg Institute of Human Rights and Humanitarian law, Copenhagen, Denmark. Email: alicekasznar@gmail.com. (1D https://orcid. org/0000-0002-3706-6420.

Astrid Bernal, Environmental Law Mg, 2013, Universidad Complutense de Madrid, Madrid, Spain; Master of Laws (LL.M.) student at Pennsylvania State University, State College, USA. Member of the Global Network for the Study of Human Rights and the Environment (GNHRE); Unsustainable livestock campaign associate at the Global Forest Coalition-GFC. Email: amb9229@psu.edu. (D) https://orcid. org/0000-0002-7257-472X.

Amy van Der KLeYn, Human Rights MA, University College London, London, United Kingdom (2018); Legal Assistant at Coram Children's Legal Centre, London, United Kingdom. Email: amykleyn@gmail.com. (D) https://orcid. org/0000-0003-3049-5131. 
La Revista de Derecho Ambiental, del Centro de Derecho Ambiental de la Facultad de Derecho de la Universidad de Chile, es un espacio de exposición y análisis en el plano académico del derecho ambiental. Su contenido se presenta a través de doctrina, jurisprudencia y recensiones, y aborda diversas materias relacionadas con la gestión, institucionalidad y herramientas de protección ambiental y desarrollo sustentable. Se presentan artículos de diferentes autores y autoras en los que se analizan y abordan casos y temas jurídico-ambientales de creciente interés y actualidad.

\author{
DIRECTORA \\ Valentina Durán Medina \\ EDITORES \\ Jorge Ossandón Rosales \\ y Antonio Pulgar Martínez \\ SITIO WEB \\ revistaderechoambiental.uchile.cl \\ CORREO ELECTRÓNICO \\ revistada@derecho.uchile.cl \\ LICENCIA DE ESTE ARTÍ́CULO \\ Creative Commons Atribución Compartir Igual 4.o Internacional
}

La edición de textos, el diseño editorial

y la conversión a formatos electrónicos de este artículo

estuvieron a cargo de Tipográfica

(www.tipografica.io) 